\title{
Growth and yield responses of sunflower to drainage in waterlogged saline soil are caused by changes in plant-water relations and ion concentrations in leaves
}

Mohammad Nazrul Islam ( $\nabla$ nazrulag@gmail.com)

Bangladesh Rice Research Institute https://orcid.org/0000-0003-0583-3952

Richard W. Bell

Edward G. Barrett-Lennard

Mohammad Maniruzzaman

\section{Research Article}

Keywords: Cultivar Hysun-33, Leaf water potential, $\mathrm{Na}+\mathrm{K}+$ ratio in leaf, Relative growth rate, SEW30, Solute potential of soil

Posted Date: March 2nd, 2022

DOI: https://doi.org/10.21203/rs.3.rs-1341552/v1

License: (c) (i) This work is licensed under a Creative Commons Attribution 4.0 International License. Read Full License 


\section{Abstract}

Purpose While proper drainage systems could improve crop growth and yield by mitigating waterlogging and salinity stresses, field evidence of the responses in plant-water relations and ion concentrations in leaves is scarce. We investigated the changes in solute potential in soil $\left(\mathrm{Y}_{\mathrm{s}}\right)$, plant-water relations and ion concentrations in leaves of sunflower caused by drainage in waterlogged saline soil, and their impacts on growth and yield.

Methods Over two growing seasons, we tested four drainage treatments: undrained, surface drains (SD; $0.1 \mathrm{~m}$ deep, $1.8 \mathrm{~m}$ apart), subsoil drains (SSD; 0.5 $\mathrm{m}$ deep, $4.5 \mathrm{~m}$ apart) and SSD+SD. All plots were inundated (2-3 cm depth; $\left.\mathrm{EC}_{\mathrm{w}} 1.5-2.5 \mathrm{dS} \mathrm{m}^{-1}\right)$ for $24 \mathrm{~h}$ at vegetative emergence and at 8-leaf stage before opening drains.

Results Relative to the most drained treatment (SSD+SD), the undrained treatment caused higher waterlogging at 0-30 $\mathrm{cm}$ depth, and decreased $\mathrm{Y}_{\mathrm{S}}$ of soil at $7.5 \mathrm{~cm}$ to $52-374 \mathrm{kPa}$, leaf $\mathrm{K}^{+}$by $5-20 \%$, stomatal conductance by $5-37 \%$ and leaf greenness by $12-25 \%$, but increased leaf $\mathrm{Na}^{+}$by $25-70 \%, \mathrm{Na}^{+} / \mathrm{K}^{+}$ ratio by $38-100 \%$ and leaf water potential by $90-250 \mathrm{kPa}$ throughout the cropping season; these changes were closely related with reduced growth and yield.

Conclusions The improved yield from the combination of shallow surface and sub-surface drains was attributed to an alleviation of salinity-waterlogging stress early in the season and to increased soil water late in the season that increased $\mathrm{Y}_{\mathrm{S}}$ and decreased $\mathrm{Na}^{+} / \mathrm{K}^{+}$ratio in leaves.

\section{Introduction}

Waterlogged saline soils are a serious threat to agricultural productivity (Barrett-Lennard 2003; Falakboland et al. 2017). Globally, around 20\% of irrigated areas are affected by secondary salinization, and one-third are facing waterlogging (Dagar and Minhas 2016). Coastal deltas, many of which are important food production regions, are at particular risk because their low elevation, flat terrain and shallow groundwater create both waterlogging and salinization of soils (van der Zee et al. 2017). Salinity and waterlogging affect morphological, physiological, and biochemical processes, seed germination, plant growth, and water and nutrient uptake (Falakboland et al. 2017; Paul et al. 2021c; Wu et al. 2015), resulting in low agricultural productivity, low-income returns and soil degradation (Hu and Schmidhalter 2004).

A major effect of salinity and/or waterlogging is the increased $\mathrm{Na}^{+}$concentration in shoots, with correspondingly lower $\mathrm{K}^{+}$and $\mathrm{K}^{+} / \mathrm{Na}^{+}$ratio in the leaf, which are correlated with reduced photosynthetic rate, stomatal conductance $\left(g_{\mathrm{s}}\right)$ and shoot growth (Akram et al. 2008; Kirmizi and Bell 2012; Saqib et al. 2005). Several researchers have reported that waterlogging and/or salinity decrease leaf water potentials ( $\Psi_{\text {leaf }}$ ), i.e., increased water stress (Akram et al. 2008; Katerji et al. 1996; Shaw 2015). By contrast, there is also evidence that $\Psi_{\text {leaf }}$ in sunflower and tomato plants can be increased rather than decreased by waterlogging (Bradford and Hsiao 1982; Jackson et al. 1978), and in these cases was associated with decreased $g_{\mathrm{s}}$ (Jackson et al. 1978). Solute potential $\left(\Psi_{s}\right)$ in the soil is also influenced by waterlogging and salinity, and the lower $\Psi_{s}$ in the salt-affected soil adversely affected sunflower growth and yield (Paul et al. 2020). Part of the differences in responses among studies may be that for many crops, the combination of waterlogging and salinity stresses have more severe impacts on plant growth and yield than either salinity or waterlogging alone (Barrett-Lennard 2003; Barrett-Lennard and Shabala 2013; Falakboland et al. 2017).

The coastal zone of Bangladesh in the Ganges Delta covers more than $30 \%$ of the total cultivable lands of the country, and around $40 \%$ of this area is affected by various degrees of soil salinity (SRDI 2010). This zone is also subject to waterlogging during heavy monsoon (aman) season rainfall, river flooding and the shallow water-table (Mainuddin et al. 2021). The excess soil water after the aman rice harvest causes waterlogging, which delays the sowing of rabi (dry season) crops. However, later planted rabi crops may be exposed to drought, pre-monsoon rainfall and salt stresses at the end of rabi season, which increase the risk of crop failure (Paul et al. 2021a). Consequently, most smallholder farms leave the land fallow in this season. In addition, heavy dry season rainfall often occurs, particularly from December to February, and creates waterlogging, which is another barrier to the rabi crop cultivation in this region (Yu et al. 2019). Our study has focused on sunflower (Hysun-33) as a typical rabi crop in the study area because of its moderate salt-tolerant and drought-adapted features (Elsheikh et al. 2012). While sunflower is a high-value crop and is becoming a popular rabi crop in this region, it is sensitive to waterlogging like other rabi crops for this area (e.g., mung bean, lentil, sesame, maize, watermelon).

Generally, drainage is important for alleviating both waterlogging and salinity for optimal plant growth and yield. Either surface or subsurface drainage is practiced in many parts of the world to alleviate these constraints. Surface drains can be effective for improving aeration and reducing salinity in the upper root zone of the growing crop (Hou et al. 2016), while deep drains (>1.75 m) are often recommended for mitigating salinity (Gupta 2002). Islam et al. (2021) found that the combination of shallow surface (10 cm depth) and subsurface drains (50 cm depth) alleviated waterlogging and salinity, and gave a 2-fold higher sunflower yield than the undrained treatment. While previous field-based studies have reported the effects of drains on waterlogging, salinity, plant morphology and yield, information has not been presented on impacts on plant water relations or ion concentrations in shoots (Ritzema et al. 2008; Sharma et al. 2000). Hence, while Islam et al. (2021) found that the combination of shallow surface and subsurface drains alleviated waterlogging and salinity and increased sunflower yield, the physiological mechanisms accounting for these responses were not determined. In contrast to previous studies under controlled (net house) conditions in coarse-textured soil, our studies were on the fine-textured soils typical of a large proportion of agricultural land in the Ganges delta.

In this study, therefore, we investigated the changes in $\Psi_{\mathrm{S}}$ in soil, plant-water relations and ion concentrations in leaves and their relation to sunflower growth and yield due to drainage in waterlogged saline soil. We examined two hypotheses to account for the range of drainage responses in sunflower. 
Firstly, early in the season, waterlogging and salinity increase the salinity of soil solution (i.e., decreased $\Psi_{\mathrm{s}}$ of the soil), leading to increases in the $\mathrm{Na}^{+} / \mathrm{K}^{+}$ ratio in leaves and water deficits (i.e., decreased $\Psi_{\text {leaf }}$ ) and decrease $g_{\mathrm{S}}$, all of which decrease growth and yield of sunflower. Secondly, in the 1 st paper (Islam et al. 2021), we also hypothesized that yield damage would occur due to decreasing soil water content and increasing soil salinity late in the season. We found this not to be true, and in this present paper, we present further information to shed light on why this occurred. In addition, we also present the decrease in soil $\Psi_{\mathrm{s}}$ late in the season by the most drained treatment and its response to reduced plant growth and yield caused by physiological changes.

\section{Materials And Methods}

\section{Experimental site and season}

The field experiments were undertaken during two consecutive dry (rabi, November-May) seasons in 2018-19 and 2019-20 on a clay-textured soil under waterlogged saline conditions in a farmer's field at Dacope, Khulna, Bangladesh $\left(22.6321^{\circ} \mathrm{N}\right.$ and $\left.89.5034^{\circ} \mathrm{E}\right)$. The experimental site is in the Ganges Tidal Floodplain (Islam et al. 2021), located in the south-western coastal region of Bangladesh. The climate is sub-tropical monsoonal with an average annual rainfall of 1,850 mm, a dry and cool winter (December-February) and a wet and hot summer (March-June) (Rahman et al. 2015). During the first cropping

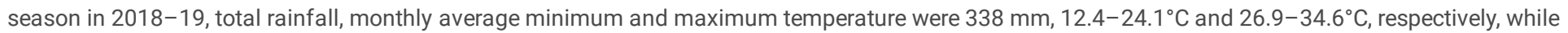
in 2019-20, total rainfall, monthly average minimum and maximum temperature were $54 \mathrm{~mm}, 13.9-20.6^{\circ} \mathrm{C}$ and $24.0-32.3^{\circ} \mathrm{C}$, respectively Islam et al. (2021). The general characteristics of soil in the experimental field were described in Islam et al. (2021).

\section{Experimental details and crop husbandry}

Drain establishment procedure, field layout and crop husbandry have been described by Islam et al. (2021). Sunflower cv. Hysun-33 was used as a test crop as it is a promising high-value rabi crop (moderately salt-tolerant and drought-adapted) for the coastal zone. In the field experiment, undrained, open surface drains (SD; $0.1 \mathrm{~m}$ deep, $1.8 \mathrm{~m}$ apart), slotted-pipe subsoil drains (SSD; $0.5 \mathrm{~m}$ deep, $4.5 \mathrm{~m}$ apart) and SSD + SD treatments were present with three replicates. Replicates of the SSD and SSD + SD treatments were blocked together to avoid hydrological interference between treatments: the rationale for this has been discussed in Islam et al. (2021).

Each plot was $10 \mathrm{~m} \times 6 \mathrm{~m}$ in size and polyethylene sheets were placed vertically around each plot to a depth of $0.6 \mathrm{~m}$ to prevent the lateral flow of water from one plot to another plot. A levee of $1 \mathrm{~m}$ wide was made between adjacent plots to minimize cross-flow of water. There were two waterlogging events in a season. The plots were inundated (2-3 cm above the soil surface) for 24 hours at both vegetative emergence (the VE stage of sunflower development, 14 days after sowing) and at the mid-vegetative stage when the crop had 8 leaves (V8 stage, Schneiter and Miller 1981). After 24 hours of inundation, drains were opened in the drainage treatments but not in the undrained treatment. The first inundation was supplied artificially using canal water (EC: 1.5$2.5 \mathrm{dS} \mathrm{m}^{-1}$ ), while the second inundation occurred naturally because of heavy rainfall (151 $\mathrm{mm}$ on $27-28$ February in the first season and $25 \mathrm{~mm}$ on 4 January in the second season, Islam et al. 2021) in both years.

Sunflower seeds were sown by dibbling on 18 January 2019 and 25 November 2019 with a row to row distance of $60 \mathrm{~cm}$ and a plant to plant distance of $30 \mathrm{~cm}$. According to the recommendation of the Bangladesh Agricultural Research Institute (Islam et al. 2021), urea-triple super phosphate-muriate of potash-gypsum-zinc sulphate-boric acid were applied at 200-200-170-170-10-12 $\mathrm{kg} \mathrm{ha}^{-1}$ in both seasons. Details of agronomic practices are given in Islam et al. (2021). The crops were harvested at physiological maturity on 29 April 2019 and 19 March 2020 in the first and second seasons, respectively.

\section{Sampling and measurements techniques}

Soil samples for EC, soil water content (SWC), waterlogging severity and soil solute potential $\left(\Psi_{\mathrm{S}}\right)$, together with stomatal conductance $\left(g_{\mathrm{s}}\right)$, leaf water potential $\left(\Psi_{\text {leaf }}\right)$ and achene yield were collected from the edge and centre of each plot. In the subsoil drainage treatments (SSD and SSD + SD), the samples were collected from the edge of the drain pipe and midway between two pipes in the centre of the plot. In the SD and control treatments, soils were sampled near the edge and centre of the plot. In addition, three plants in each plot were randomly sampled and composited to one sample for measuring shoot dry weight (SDW) and leaf $\mathrm{Na}^{+}$and $\mathrm{K}^{+}$concentrations.

\section{Solute potential}

The three soil samples that were collected from each of the positions (centre and edge) at each depth $(0-15,15-30,30-45$, and $45-60 \mathrm{~cm})$ were mixed thoroughly to make a composite sample for each depth. Soil samples were collected at 7 and 14 days after first inundation (DAFI), 10 and 17 days after second inundation (DASI), 30-50\% flowering (FL) and harvest (HRV). The gravimetric method (oven-drying) was used for measuring soil water content (SWC). The $\mathrm{EC}_{1: 5}$ was measured by mixing $10 \mathrm{~g}$ of air-dried soil with $50 \mathrm{~mL}$ of distilled water. Solute potential $\left(\Psi_{\mathrm{s}}\right)$ of the soil solutions was calculated using the following equation (Paul et al. 2020).

$\Psi_{\mathrm{S}}=-22580 \times \mathrm{EC}_{1: 5} / \mathrm{W}$

Where $\Psi_{\mathrm{s}}$ is the solute potential $(\mathrm{kPa}), \mathrm{EC}_{1: 5}$ is the electrical conductivity $(\mathrm{dS} / \mathrm{m})$ of an extract from soil to water ratio of $1: 5$, and $\mathrm{W}$ is the soil water content $(\%, w / w)$.

\section{Waterlogging $\left(\mathrm{SEW}_{30}\right)$}


The sum of excess water in the $0-30 \mathrm{~cm}$ layer $\left(\mathrm{SEW}_{30}\right)$, referred to as waterlogging, was measured daily throughout the season according to the method of Sieben (1964) and Cox (1988). Details of this have been presented in Islam et al. (2021).

\section{Stomatal conductance and leaf water potential}

Stomatal conductance $\left(g_{\mathrm{S}}\right)$ and leaf water potential ( $\left.\Psi_{\text {leaf }}\right)$ were measured with a leaf porometer (SC-1 Leaf Porometer, Decagon Devices, USA) and a Pressure Chamber Instrument (Model-1000, PMS Instrument Company, USA), respectively. In the first season (2019), we measured $g_{\mathrm{s}}$ at 3 DASI, 10 DASI and $17 \mathrm{DASI}$, and $\psi_{\text {leaf }}$ at $3 \mathrm{DASI}$ and FL. In the second season (2019-20), $\psi_{\text {leaf }}$ was measured at 3 DASI, 10 DASI, 17 DASI and FL. Three plants were selected randomly from each position (the edge and centre in a plot), and one fully expanded youngest leaf from each plant was measured for $g_{\mathrm{s}}$ and $\Psi_{\text {leaf }}$. Measurements were taken between noon and $2 \mathrm{pm}$.

\section{Shoot dry weight and relative growth rate of shoot}

Four shoots were collected randomly from each plot before first inundation, $7 \mathrm{DAFI}, 14 \mathrm{DAFI}, 10 \mathrm{DASI}, 17 \mathrm{DASI}$ and $\mathrm{FL}$, and were dried in an oven at $70^{\circ} \mathrm{C}$ for $72 \mathrm{~h}$ and weighed. The relative growth rate (RGR) for the single shoot was calculated following Hunt (1982).

$$
R G R=\frac{\ln \left(W_{2}\right)-\ln \left(W_{1}\right)}{t_{2}-t_{1}}
$$

where $W_{1}$ and $W_{2}$ are shoot dry weights at times $t_{1}$ and $t_{2}$.

\section{Leaf $\mathrm{Na}^{+}$and $\mathrm{K}^{+}$concentrations and the $\mathrm{Na}^{+} / \mathrm{K}^{+}$ratio}

Three plants were randomly selected in each plot and all leaves at $7 \mathrm{DAFI}$, the 2-3 youngest fully expanded and the oldest live leaf blades at $10 \mathrm{DASI}$ and flowering from each plant were detached from the petiole. Leaves were then rinsed in deionized water $\left(E C \sim 0.0 \mu S \mathrm{~cm}^{-1}\right)$, blotted with tissue paper and dried in an oven at $70^{\circ} \mathrm{C}$ for $72 \mathrm{~h}$. About $0.2 \mathrm{~g}$ of ground leaves were digested by di-acid mixture (nitric and perchloric acid of $5: 2$ ratio), Na ${ }^{+}$and $\mathrm{K}^{+}$were measured with a flame photometer (Model: 410, Sherwood) (Yamakawa 1992). The concentration of ions was expressed in mmol kg ${ }^{-1}$ and the ratio of $\mathrm{Na}^{+}$ and $\mathrm{K}^{+}$was calculated.

\section{Statistical analysis}

STAR software (version 2.0.1) was used to do the analysis of variance (ANOVA). The regression analyses for different factors were done using Jamovi software (version 1.1.9.0) and the graphs were prepared using Microsoft Office 365. One-way ANOVA was used to test the significance of the effects of the drains on SDW, RGR, $\mathrm{Na}^{+}$and $\mathrm{K}^{+}$concentration in leaf, ratio of $\mathrm{Na}^{+}$and $\mathrm{K}^{+}$. The effects of drains and position within the plot on $g_{\mathrm{S}} \Psi_{\text {leaf }}$ and leaf chlorophyll content (LCC) were measured using two-way ANOVA. The significance of the effects of the drain on $\Psi_{\mathrm{S}}$ of soil was determined using three-way (treatment, position and soil depth) factorial ANOVA models that also considered the effects of soil depth as a repeated measure. The comparison of means was made using the least significant difference (LSD) at $P=0.05$. Single-factor regression analysis was done to investigate the relationship between achene yield or SDW and $\Psi_{\mathrm{S}}$ of soil or $g_{\mathrm{S}}$ or $\Psi_{\text {leaf }}$ or LCC or $\mathrm{Na}^{+}$or $\mathrm{K}^{+}$or $\mathrm{Na}^{+} / \mathrm{K}^{+}$in leaves at different times. The correlations of $\mathrm{Na}^{+}$or $\mathrm{K}^{+}$or $\mathrm{Na}^{+} / \mathrm{K}^{+}$ in leaves with $\Psi_{\mathrm{S}}$ or $\mathrm{EC}_{1: 5}$ or $\mathrm{SEW}_{30}$ at different times during the cropping season were also tested using single factor regression analysis. We also tested relationships among different factors $\left(\Psi_{\mathrm{S}}, \mathrm{EC}_{1: 5}, g_{\mathrm{S}}, \mathrm{LCC}, \Psi_{\text {leaf }}\right.$ and $\left.\mathrm{SEW} \mathrm{W}_{30}\right)$ during the crop growing season.

\section{Results}

In our previous study (Islam et al. 2021) drainage treatments showed up to 50\% increase in achene yield in sunflower relative to the undrained treatment under waterlogged saline conditions in 2018-19 and 2019-20. In this paper, we were seeking physiological causes for these effects. Here, there was a consistency between years in response to drainage treatments in waterlogged saline soil for all parameters measured (ion concentrations in leaves, leaf water potential, shoot growth rate and soil solute potential), but values in the first (2018-19) and second year (2019-20) differed slightly due to variations in rainfall, temperature, soil salinity, and dates of planting, waterlogging and harvesting.

\section{Concentrations of $\mathrm{Na}^{+}$and $\mathrm{K}^{+}$in leaves and their ratio $\left(\mathrm{Na}^{+} / \mathrm{K}^{+}\right)$}

In both years, $\mathrm{Na}^{+}$concentration and $\mathrm{Na}^{+} / \mathrm{K}^{+}$ratio in all leaves at $7 \mathrm{DAFI}$ and in the older leaves at $10 \mathrm{DASI}$ and $\mathrm{FL}$ were decreased by drainage treatments compared with the undrained treatment, while the $\mathrm{K}^{+}$concentration was increased (Fig. 1). At $7 \mathrm{DAFI}$, the lowest leaf $\mathrm{Na}^{+}$concentration was found in the most drained (SSD + SD) treatment (838 mmol kg-1 in 2018-19 and $485 \mathrm{mmol} \mathrm{kg}^{-1}$ in 2019-20), whereas the highest was with undrained treatment (1374 mmol kg-1 in 2018-19 and $825 \mathrm{mmol} \mathrm{kg}^{-1}$ in 2019-20). The SD and SSD treatments had $\mathrm{Na}^{+}$concentrations between the SSD + SD treatment and the undrained treatment. Similar trends were observed at 10 DASI and FL (Fig. 1). By contrast, leaf $\mathrm{K}^{+}$concentrations at 7 DAFI, 10 DASI and FL were $894-$ $972 \mathrm{mmol} \mathrm{kg}^{-1}$ in 2018-19 and 980-1023 mmol kg-1 in 2019-20 with most drained treatment and 764-926 mmol kg-1 in 2018-19 and 788-938 mmol $\mathrm{kg}^{-1}$ in 2019-20 with the undrained treatment (Fig. 1). In both years, the most drained treatment had the lowest $\mathrm{Na}^{+} / \mathrm{K}^{+}$ratio at $7 \mathrm{DAFI}($ all leaves), $10 \mathrm{DASI}$ (older leaves) and FL (older leaves), which was 9-37, 19-32 and 32-52\% lower than the SSD, SD and undrained treatments, respectively (Fig. 1). However, younger leaves did not show significant changes in leaf ion concentration or the $\mathrm{Na}^{+} / \mathrm{K}^{+}$ratio (Supplementary Material, Fig. S1). 
Leaf $\mathrm{Na}^{+}$concentration and $\mathrm{Na}^{+} / \mathrm{K}^{+}$ratio during the season were significantly and negatively associated with achene yield, while leaf $\mathrm{K}^{+}$positively correlated with the achene yield (Figs. 2 and 3; yield data reported in Islam et al. 2021). Leaf $\mathrm{Na}^{+}$concentration at different times explained $46-81 \%$ and $40-81 \%$ of the yield variation in 2018-19 (Fig. 2) and 2019-20 (Fig. 3), respectively. The achene yield variation explained by $\mathrm{K}^{+}$concentration ranged from 53 to $70 \%$ in $2018-19$ and 50 to $75 \%$ in $2019-20$. The $\mathrm{Na}^{+} / \mathrm{K}^{+}$ratio explained $50-79 \%$ of the yield variation in $2018-19$ and $64-86 \%$ in $2019-20$. The younger leaves showed weak relationships between the ion parameters and achene yield compared with older leaves.

In both years, increased $\mathrm{SEW}_{30}$ and soil $\mathrm{EC}_{1: 5}$ at 0-15 cm, and decreased $\Psi_{\mathrm{S}}$ at 0-15 $\mathrm{cm}$ were significantly correlated with increased $\mathrm{Na}^{+}$, decreased $\mathrm{K}^{+}$and increased $\mathrm{Na}^{+} / \mathrm{K}^{+}$in leaves at different times during the crop growing season (Table 1). However, younger leaves showed either no relationship or weak relationships, particularly at flowering. The SEW 30 explained $60-76,52-54$ and $56-73 \%$ of the variation in $2018-19$ and $47-84,43-79$ and $34-89 \%$ of the variation in 2019-20 in leaf $\mathrm{Na}^{+}, \mathrm{K}^{+}$and $\mathrm{Na}^{+} / \mathrm{K}^{+}$respectively. The strongest correlations with $\mathrm{Na}^{+}\left(\mathrm{r}^{2}=0.76\right), \mathrm{K}^{+}\left(\mathrm{r}^{2}=0.63\right)$ and Na$/ \mathrm{K}^{+}\left(\mathrm{r}^{2}=0.73\right)$ were observed in the older leaves at 10 DASI in 2018-19. In 2019-20, leaf $\mathrm{Na}^{+}\left(r^{2}=0.84\right)$ and $\mathrm{Na}^{+} / \mathrm{K}^{+}\left(r^{2}=0.89\right)$ showed similar response but leaf $\mathrm{K}^{+}\left(r^{2}=0.79\right)$ showed strongest correlation at $7 \mathrm{DAFI}$. In the case of soil $\mathrm{EC}_{1: 5}$, the $\mathrm{r}^{2}$ values for $\mathrm{Na}^{+}, \mathrm{K}^{+}$and $\mathrm{Na}^{+} / \mathrm{K}^{+}$were $0.49-0.72,0.39-0.84$ and $0.54-0.74$, respectively in 2018-19 and $0.46-0.86,0.43-0.78$ and $0.72-0.90$ in 2019-20. The strongest correlations with $\mathrm{Na}^{+}\left(r^{2}=0.72\right.$ in $2018-19$ and 0.86 in 2019-20) and $\mathrm{Na}^{+} / \mathrm{K}^{+}\left(\mathrm{r}^{2}=0.74\right.$ in 2018-19 and 0.90 in 2019-20) were observed in the older leaves at FL in both years. The strongest correlation with $\mathrm{K}^{+}$ $\left(r^{2}=0.84\right)$ were observed in the young leaves at 10 DASI in 2018-19, but in 2019-20 the correlation was strongest $\left(r^{2}=0.78\right)$ in the older leaves at 10 DASI.

The soil $\Psi_{\mathrm{s}}$ also showed significant linear relationship with leaf $\mathrm{Na}^{+}\left(\mathrm{r}^{2}\right.$ values of $0.58-0.75$ in $2018-19$ and $0.44-0.85$ in $\left.2019-20\right), \mathrm{K}^{+}\left(\mathrm{r}^{2}\right.$ values of $0.46-$ 0.77 and $0.47-0.70$ in 2018-19 and 2019-20, respectively) and $\mathrm{Na}^{+} / \mathrm{K}^{+}\left(\mathrm{r}^{2}\right.$ values of $0.42-0.78$ in $2018-19$ and $0.37-0.92$ in $\left.2019-20\right)$ in both years although no correlation was found at 7 DAFI in 2018-19 (Table 1). The strongest correlation with leaf $\mathrm{Na}^{+}$and $\mathrm{Na}^{+} / \mathrm{K}^{+}$occurred in the older leaves at FL in both years. However, the strongest correlation with leaf $\mathrm{K}^{+}$differed between years. In 2018-19, it was highest in the young leaves at 10 DASI, while in 2019-20, it was highest in the older leaves at 10 DASI.

Table 1. Significance of effects of $\mathrm{SEW}_{30}$, soil $\mathrm{EC}_{1: 5}$ at $0-15 \mathrm{~cm}$ and $\Psi_{\mathrm{s}}$ at $0-15 \mathrm{~cm}$ on $\mathrm{Na}^{+}, \mathrm{K}^{+}$and $\mathrm{Na}^{+} / \mathrm{K}^{+}$in leaves at different times during the growing season in 2018-19 and 2019-20. 


\begin{tabular}{|c|c|c|c|c|c|c|}
\hline & \multicolumn{6}{|c|}{ Significance level with $r^{2}$ values and direction of the slope (in brackets) } \\
\hline & \multicolumn{3}{|l|}{ 2018-19 } & \multicolumn{3}{|l|}{$2019-20$} \\
\hline & $\begin{array}{l}\mathrm{SEW}_{30} \\
\text { (cm days) }\end{array}$ & $\begin{array}{l}\mathrm{EC}_{1: 5} \\
\left(\mathrm{dS} \mathrm{m} \mathrm{m}^{-1}\right)\end{array}$ & $\begin{array}{l}Y_{s} \\
(k P a)\end{array}$ & $\begin{array}{l}\mathrm{SEW}_{30} \\
\text { (cm days) }\end{array}$ & $\begin{array}{l}\mathrm{EC}_{1: 5} \\
\left(\mathrm{dS} \mathrm{m} \mathrm{m}^{-1}\right)\end{array}$ & $\begin{array}{l}Y_{s} \\
(k P a)\end{array}$ \\
\hline \multicolumn{7}{|l|}{ At 7 DAFI } \\
\hline $\mathrm{Na}^{+}(\mathrm{AL})$ & $(+) 0.74^{\star \star \star}$ & $(+) 0.57 * \star$ & NS & $(+) 0.81^{\star \star \star}$ & $(+) 0.72^{\star \star \star}$ & $(-) 0.63^{\star \star}$ \\
\hline $\mathrm{K}^{+}(\mathrm{AL})$ & $(-) 0.52^{\star *}$ & $(-) 0.41^{\star}$ & NS & $(-) 0.79 * \star$ & $(-) 0.59 * *$ & $(+) 0.47 *$ \\
\hline $\mathrm{Na}^{+} / \mathrm{K}^{+}(\mathrm{AL})$ & $(+) 0.73^{\star \star \star}$ & $(+) 0.60 * \star$ & NS & $(+) 0.88 * \star \star$ & $(+) 0.73^{\star \star \star}$ & $(-) 0.61 \star \star$ \\
\hline \multicolumn{7}{|l|}{ At 10 DASI } \\
\hline $\mathrm{Na}^{+}(\mathrm{YL})$ & NS & (+) $0.49 *$ & $(-) 0.58^{\star \star \star}$ & (+) $0.47 *$ & (+) $0.46^{*}$ & $(-) 0.44^{\star}$ \\
\hline $\mathrm{K}^{+}(\mathrm{YL})$ & $(-) 0.54^{\star \star}$ & $(-) 0.84^{\star \star \star}$ & $(+) 0.77 \star \star \star$ & $(-) 0.43^{\star}$ & $(-) 0.72^{\star \star \star}$ & (+) $0.57^{* *}$ \\
\hline $\mathrm{Na}^{+} / \mathrm{K}^{+}(\mathrm{YL})$ & NS & (+) $0.54^{\star \star}$ & $(-) 0.62^{\star \star}$ & (+) $0.61^{\star \star}$ & (+) $0.73^{\star \star \star}$ & $(-) 0.65^{\star \star}$ \\
\hline $\mathrm{Na}^{+}(\mathrm{OL})$ & (+) $0.76^{\star \star \star}$ & $(+) 0.62 * \star$ & NS & (+) $0.84^{\star \star *}$ & (+) $0.60 * \star$ & $(-) 0.48 *$ \\
\hline $\mathrm{K}^{+}(\mathrm{OL})$ & $(-) 0.63^{\star \star \star}$ & $(-) 0.74^{\star \star \star}$ & $(+) 0.53^{\star \star}$ & $(-) 0.71^{\star \star \star}$ & $(-) 0.78^{\star \star \star}$ & (+) $0.70^{* \star *}$ \\
\hline $\mathrm{Na}^{+} / \mathrm{K}^{+}(\mathrm{OL})$ & (+) $0.73^{\star \star \star}$ & 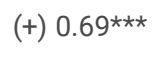 & $(-) 0.42^{\star}$ & 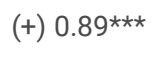 & (+) $0.72^{\star \star \star}$ & $(-) 0.60 \star \star *$ \\
\hline \multicolumn{7}{|l|}{ At FL } \\
\hline $\mathrm{Na}^{+}(\mathrm{YL})$ & NS & NS & NS & NS & NS & NS \\
\hline $\mathrm{K}^{+}(\mathrm{YL})$ & NS & $(-) 0.49 *$ & (+) $0.46^{*}$ & NS & $(-) 0.43^{\star}$ & $(+) 0.48^{*}$ \\
\hline $\mathrm{Na}^{+} / \mathrm{K}^{+}(\mathrm{YL})$ & NS & NS & NS & $(+) 0.34^{*}$ & NS & $(-) 0.37^{\star}$ \\
\hline $\mathrm{Na}^{+}(\mathrm{OL})$ & (+) $0.60 \star *$ & (+) $0.72^{\star \star *}$ & $(-) 0.75^{\star \star \star}$ & (+) $0.70^{\star \star \star}$ & (+) $0.86^{\star \star \star}$ & $(-) 0.85^{\star \star \star}$ \\
\hline $\mathrm{K}^{+}(\mathrm{OL})$ & NS & $(-) 0.39 *$ & $(+) 0.42^{\star}$ & NS & (-) $0.57 \star \star$ & $(+) 0.60^{\star \star}$ \\
\hline $\mathrm{Na}^{+} / \mathrm{K}^{+}(\mathrm{OL})$ & (+) $0.56^{\star \star}$ & 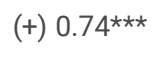 & 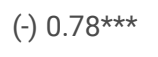 & (+) $0.68 * \star \star$ & 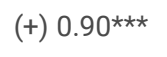 & $(-) 0.92^{\star \star \star}$ \\
\hline
\end{tabular}

Abbreviations: $\mathrm{DAFI}=$ days after first inundation, $\mathrm{DASI}=$ days after second inundation, $\mathrm{FL}=$ flowering, $\mathrm{AL}=$ all leaves, $\mathrm{YL}=$ younger leaves, $\mathrm{OL}=$ older leaves, $\mathrm{Y}_{\mathrm{S}}=$ solute potential, ${ }^{*}=P<0.05,{ }^{*}=P<0.01$, ${ }^{\star \star *}=P<0.001, \mathrm{NS}=$ non-significant. For all relationships $n=12$.

\section{Stomatal conductance, leaf water potential and leaf chlorophyll content}

There was a significant difference $(P<0.001)$ in stomatal conductance $\left(g_{\mathrm{s}}\right)$ among the treatments at 3 DASI but no difference at 10 and 17 DASI $($ Table 2$)$. The combined drain treatment (SSD+SD) showed the highest $g_{\mathrm{s}}\left(633 \mathrm{mmol} \mathrm{m}^{-2} \mathrm{~s}^{-1}\right)$, while the lowest $g_{\mathrm{s}}$ was with the undrained treatment $\left(401 \mathrm{mmol} \mathrm{m}^{-2}\right.$ $\mathrm{s}^{-1}$ ) at $3 \mathrm{DASI}$, compared with the $g_{\mathrm{s}}$ of $552 \mathrm{mmol} \mathrm{m}^{-2} \mathrm{~s}^{-1}$ for SSD and $562 \mathrm{mmol} \mathrm{m}^{-2} \mathrm{~s}^{-1}$ for SD treatments. Drainage treatments also influenced the leaf water potential $\left(\mathrm{Y}_{\text {leaf }}\right.$ ) at different times in both years (Table 3). In 2018-19, the lowest $Y_{\text {leaf }}$ was with the SSD+SD treatment (-1.29 to -1.40 MPa) during the season, while the highest $Y_{\text {leaf }}$ was with the undrained treatment (-1.18 to $\left.-1.25 \mathrm{MPa}\right)$. There was no difference between SD and SSD treatments. Similar trend was observed in 2019-20, showing the lowest $Y_{\text {leaf }}$ of -1.27 to $-1.58 \mathrm{MPa}$ with the most drained treatment and the highest $\mathrm{Y}_{\text {leaf }}$ of -1.16 to $-1.33 \mathrm{MPa}$ with the undrained treatment) throughout the cropping season.

Measurements of leaf chlorophyll content (LCC) are reported in the Supplementary Materials (Table S1) with the units of chlorophyll content index (CCI). In 2018-19, the most drained treatment had the highest LCC (12.0-17.2 CCI) throughout the season, whereas the undrained treatment had the lowest LCC (9.0-14.8 CCI) (Supplementary Material, Table S1). The variation in LCC between SD and SSD was not significant, although the values were higher than the undrained treatment but lower than the SSD+SD treatment. In 2019-20, the response of LCC to drainage treatments was similar to the previous year. The ranges of LCC during the crop growing season in SSD+SD, SSD, SD and undrained treatments were 13.7-23.1, 12.1-21.0, 12.2-21.4 and 11.3-19.2 CCI, respectively.

The achene yield was significantly associated with $g_{\mathrm{s}}$ (positive correlation; one year of data only), $\mathrm{Y}_{\text {leaf }}$ (negative correlation) and LCC (positive correlation) in both years (Supplementary Material, Table S2). The $g_{S}, Y_{\text {leaf }}$ and LCC accounted for 17-68, 45-67 and 47-69\% of the variation in achene yield, respectively. In most cases, the greatest variation was observed at $3 \mathrm{DASI}$ at $P<0.001$. In addition, soil $\mathrm{Y}_{\mathrm{S}}, \mathrm{EC}_{1: 5}$ at $0-15 \mathrm{~cm}$ soil depth and $\mathrm{SEW} 30$ all showed significant relationships with $g_{\mathrm{S}}, \mathrm{LCC}$ and $\mathrm{Y}_{\text {leaf }}$ at different times during the cropping season (Supplementary Material, Table S3). The $\mathrm{Y}_{\mathrm{s}}$ in soil was 
positively correlated with $g_{\mathrm{s}}\left(r^{2}=0.45\right.$ at $\left.17 \mathrm{DASI}\right)$ and LCC $\left(r^{2}\right.$ values of $\left.0.33-0.67\right)$, and negatively correlated with $\mathrm{Y}_{\text {leaf }}\left(r^{2}\right.$ values of $\left.0.44-0.63\right)$. The strongest correlations with $g_{\mathrm{S}}, \mathrm{LCC}$ and $\mathrm{Y}_{\text {leaf }}$ were at $17 \mathrm{DASI}, \mathrm{FL}$ and FL, respectively. In contrast, the soil EC $\mathrm{E}_{1: 5}$ gave a negative correlation with $g_{\mathrm{S}}\left(\mathrm{r}^{2}=0.34\right.$ at $17 \mathrm{DASI})$ and LCC $\left(r^{2}\right.$ values of $\left.0.59-0.74\right)$, and a positive correlation with $\mathrm{Y}_{\text {leaf }}\left(\mathrm{r}^{2}\right.$ values of $\left.0.42-0.63\right)$. The strongest relationships with $g_{s^{\prime}}$ LCC and $Y_{\text {leaf }}$ were at 17 DASI, FL and FL, respectively. The SEW 30 also showed negative correlation with $g_{\mathrm{S}}\left(r^{2}\right.$ values of $\left.0.19-0.80\right)$ and LCC $\left(r^{2}\right.$ values of $0.57-$ $0.90)$, and a positive correlation with $Y_{\text {leaf }}\left(r^{2}\right.$ values of $\left.0.25-0.68\right)$. The highest $r^{2}$ values were observed at 3 DASI. The results also showed that plant height (Supplementary Material, Fig. S2) and leaf area (Supplementary Material, Fig. S3) were negatively correlated with $Y_{\text {leaf }}$ at 3 DASI and at FL in both years. Plant height and leaf area explained $58-64 \%$ and $56-72 \%$ of the variation in $\mathrm{Y}_{\text {leaf, }}$, respectively.

Table 2. Effects of drains on stomatal conductance at different times in 2018-19.

\begin{tabular}{|llll|}
\hline Treatment & \multicolumn{2}{l|}{$\begin{array}{l}\text { Stomatal conductance } \\
\left(\mathrm{mmol} \mathrm{m}^{-2} \mathrm{~s}^{-1}\right)\end{array}$} \\
\cline { 2 - 4 } & $3 \mathrm{DASI}$ & $10 \mathrm{DASI}$ & 17 DASI \\
\hline SSD+SD & $633 \mathrm{a}$ & 944 & 955 \\
\hline SSD & $552 \mathrm{~b}$ & 946 & 952 \\
\hline SD & $562 \mathrm{~b}$ & 937 & 947 \\
\hline Undrained & $401 \mathrm{c}$ & 900 & 898 \\
\hline$P$-value & $<0.001$ & NS & NS \\
\hline
\end{tabular}

Means with the same letter are not significantly different at $5 \%$ level of significance. Abbreviations: SSD = subsoil drain, SD = surface drain, DASI = days after second inundation.

Table 3. Effects of drains on leaf water potential at different times in 2018-19 and 2019-20.

\begin{tabular}{|c|c|c|c|c|c|c|c|c|}
\hline \multirow[t]{3}{*}{ Treatment } & \multicolumn{8}{|c|}{ Leaf water potential (MPa) } \\
\hline & \multicolumn{4}{|c|}{ 2018-19 } & \multicolumn{4}{|c|}{$2019-20$} \\
\hline & 3 DASI & 10 DASI & 17 DASI & $\mathrm{FL}$ & 3 DASI & $10 \mathrm{DASI}$ & 17 DASI & $\mathrm{FL}$ \\
\hline SSD+SD & $-1.29 c$ & - & - & $-1.27 b$ & $-1.29 b$ & $-1.35 b$ & $-1.58 c$ & $-1.27 b$ \\
\hline SSD & $-1.22 a b$ & - & - & $-1.19 a b$ & $-1.22 \mathrm{a}$ & $-1.27 \mathrm{a}$ & $-1.44 b$ & $-1.19 a b$ \\
\hline SD & $-1.24 b$ & - & - & $-1.22 b$ & $-1.25 a b$ & $-1.29 a b$ & $-1.47 b$ & $-1.22 b$ \\
\hline Undrained & $-1.18 \mathrm{a}$ & - & - & $-1.16 a$ & $-1.20 \mathrm{a}$ & $-1.25 a$ & $-1.33 a$ & $-1.16 a$ \\
\hline$P$-value & $<0.01$ & - & - & $<0.001$ & $<0.01$ & $<0.05$ & $<0.001$ & $<0.001$ \\
\hline
\end{tabular}

Means with the same letter are not significantly different at $5 \%$ level of significance. Abbreviations: SSD = subsoil drain, SD = surface drain, DASI = days after second inundation, $\mathrm{FL}=$ flowering.

\section{Solute potential}

The drainage treatments and soil depths significantly influenced solute potential $\left(\mathrm{Y}_{\mathrm{s}}\right)$ in the soil at different times during the crop growing season in $2018-$ 19 (Fig. 4) and 2019-20 (Fig. 5). In both years, the treatments and soil depths showed interaction effects throughout the sunflower growing period, but no interaction was found between treatments and position in the plot, or between depth and position. In general, the lowest $Y_{S}$ was measured in the undrained treatment (-148 to $-614 \mathrm{kPa}$ in $2018-19$ and -75 to $-555 \mathrm{kPa}$ in $2019-20)$, while in most cases, the highest $\mathrm{Y}_{\mathrm{S}}$ was with the SSD+SD treatment (-79 to -482 $\mathrm{kPa}$ in $2018-19$ and -51 to $-300 \mathrm{kPa}$ in 2019-20) throughout the cropping season. Late in the sunflower growing season (FL-HRV), the $\mathrm{Y}_{\mathrm{s}}$ in the undrained treatment was either lower or similar to the most draining treatment (SSD+SD). The $Y_{S}$ was lowest at the upper soil (average depth $7.5 \mathrm{~cm}$ ) and increased sharply at average depth $22.5 \mathrm{~cm}$. The values from average depths of 22.5 to $52.5 \mathrm{~cm}$ remained almost stable or slightly increased in SD and undrained treatments, while the SSD and SSD+SD treatments showed decreasing trends. Finally, at the deeper soil (average depth $52.5 \mathrm{~cm}$ ), there was a little variation of $\mathrm{Y}_{\mathrm{S}}$ among the treatments.

At average depth $7.5 \mathrm{~cm}$, the higher $\mathrm{Y}_{\mathrm{S}}$ was with SSD+SD treatment (-87 to $-482 \mathrm{kPa}$ ) and the lower values with the undrained treatment (-177 to $-614 \mathrm{kPa}$ ) throughout the season in both years. The SSD and SD treatments had a similar $Y_{\mathrm{S}}$ in the topsoil (average depth $7.5 \mathrm{~cm}$ ), but at average depth $22.5 \mathrm{~cm}$, the SSD treatment had higher $Y_{S}$ than the SD treatment. Increasing $Y_{S}$ at average depth $7.5 \mathrm{~cm}$ during the cropping season was significantly correlated with increasing sunflower yield with $r^{2}$ values of $0.29-0.92$ in 2018-19 and 0.51-0.77 in 2019-20 (Fig. 6). In both years, the strongest relationship was observed at FL. 


\section{Relative growth rate and dry weight of shoot}

The dry weight data used to calculate the relative growth rate (RGR) of the shoots are reported in Supplementary Materials (Table S4). In 2018-19, the RGR of the shoot during the period of T1 (before inundation, BI, to 7 DAFI), T2 (7 DAFI to 14 DAFI) and T3 (10 DASI to 17 DASI) were highest in the most drained treatment (0.07-0.17 $\mathrm{g} \mathrm{g}^{-1} \mathrm{~d}^{-1}$ ) (Fig. 7). In contrast, the lowest RGR occurred in the undrained treatment $\left(0.03-0.11 \mathrm{~g} \mathrm{~g}^{-1} \mathrm{~d}^{-1}\right)$ during T1 and T2, but the values were higher than both SD and SSD treatments at T3. There was no variation among the treatments at T4. Similarly, in 2019-20, the undrained treatment had the lowest RGR during T1-T3 $\left(0.06-0.11 \mathrm{~g} \mathrm{~g}^{-1} \mathrm{~d}^{-1}\right)$, and at T4, the values were similar to other treatments (Fig. 7). In contrast, the highest RGR was in the SSD+SD treatments, although the values were not different from SD and SSD treatments at T1, T3 and T4.

In both years, the shoot dry weight at different times during the study period showed strong negative correlations with SEW $30\left(r^{2}\right.$ values of $0.85-0.95$ in 2018-19, and 0.82-0.94 in 2019-20) and soil EC 1:5 $_{\text {( }}{ }^{2}$ values of 0.66-0.93 in 2018-19, and 0.69-0.84 in 2019-20) (Supplementary Material, Figs. S4 and S5). In contrast, there were positive linear relationships with $Y_{S}$ in soil, which explained $41-90$ and $52-86 \%$ of the variation in shoot dry weight in 2018-19 and 2019-20, respectively (Supplementary Material, Fig. S6). In addition, the higher shoot dry weights at different times throughout the season were significantly correlated with higher leaf $\mathrm{K}^{+}\left(r^{2}\right.$ values between 0.46 and 0.73 in 2018-19, and 0.47 and 0.80 in 2019-20) and lower leaf $\mathrm{Na}^{+}\left(\mathrm{r}^{2}\right.$ values between 0.78 and 0.80 in 2018-19, and 0.47 and 0.82 in 2019-20) and $\mathrm{Na}^{+} / \mathrm{K}^{+}$ratio $\left(\mathrm{r}^{2}\right.$ values ranged $0.34-0.78$ in 2018-19, and $0.65-0.90$ in 2019-20) (Supplementary Material, Figs. S7 and S8). The LCC also showed positive and linear relationships with shoot dry weight, which accounted for 75-89 and $62-80 \%$ of the variation in 2018-19 and 2019-20, respectively (Supplementary Material, Fig. S9).

\section{Discussion}

Although sunflower is a moderately salt-tolerant crop, this study shows that the plant is adversely affected by elevated concentrations of $\mathrm{Na}^{+}$in leaves. Previous studies have focused on the interaction between waterlogging and salinity and focusing the fact that waterlogging increases the concentration of $\mathrm{Na}^{+}$in leaves (Barrett-Lennard 2003; Barrett-Lennard and Shabala 2013). In our previous paper (Islam et al. 2021), we reported that a combination of shallow drains (SSD with $0.5 \mathrm{~m}$ depth and SD with $0.1 \mathrm{~m}$ depth) yielded 20-37, 16-45 and 92-95\% higher achene weight than SSD, SD and undrained treatments, respectively. Here we investigated the possible mechanisms behind these growth and yield responses in sunflower to drainage treatments under waterlogged saline conditions. We found that the yield responses were correlated with higher $\mathrm{Y}_{\mathrm{S}}$, leaf $\mathrm{K}^{+}$and $g_{\mathrm{S}}$, and lower leaf $\mathrm{Na}^{+}$, leaf $\mathrm{Na}^{+} / \mathrm{K}^{+}$ratio and $Y_{\text {leaf. }}$ This discussion focuses on two hypotheses. In accord with our first hypothesis, we found that the undrained treatment decreased the $Y_{S}$ of the soil relative to the drained treatments, and this decreased $\mathrm{Y}_{\mathrm{S}}$ was correlated with an increased $\mathrm{Na}^{+} / \mathrm{K}^{+}$ratio in leaves and $\mathrm{Y}_{\text {leaf }}$ decreased $g_{\mathrm{S}}$ and achene yield. Contrary to the second hypothesis, we found that SSD+SD treatments actually increased SWC and reduced soil $\mathrm{EC}_{1: 5}$ late in the season, resulting in increased $Y_{s}$ and reduced $Y_{\text {leaf }}$ and $\mathrm{Na}^{+}$concentration in leaves. The discussion below focuses further on these two families of effects.

\section{Waterlogging and salinity early in the growing season reduce soil solute potential, leading to decreases in plant growth and yield}

This section of the discussion focuses on two possible sequences of physiological changes (causes and effects) that could have occurred early in the growing season. We have termed these the 'adverse ion relations' and 'stomatal closure' sequences (Fig. 8).

\section{Adverse ion relations}

In saline soils that waterlog, drainage has the potential to overcome adverse ion relations in plants (i.e., increased $\mathrm{Na}^{+}$, decreased $\mathrm{K}^{+}$, increased $\mathrm{Na}^{+} / \mathrm{K}^{+}$) in two ways: by decreasing soil salinity (i.e., increasing $Y_{s}$ ) (c.f. Munns 2002) and by improving soil aeration thereby overcoming adverse waterloggingsalinity interactions (c.f. Barrett-Lennard 2003; Barrett-Lennard and Shabala 2013). In overview, our data suggest that there are beneficial effects of drainage on ion relations which may occur through both mechanisms.

The $Y_{S}$ of the soil is proportional to the salt concentration in the soil and is inversely related to the soil water content of the soil (Rengasamy 2006). Since $\mathrm{Y}_{\mathrm{S}}$ incorporates both soil salt and water content, it has the potential to explain better salt effects on plant growth and yield than either SWC or soil EC alone (Ben-Gal et al. 2009; Paul et al. 2020). In our previous paper (Islam et al. 2021), the shallow combined drain treatment decreased $\mathrm{SEW}_{30}$ and soil $\mathrm{EC}_{1: 5}$ at 0-60 cm depth by 60-63 and 35-52\%, respectively, early in the season (7 DAFI to $17 \mathrm{DASI}$ ) relative to the undrained treatment. This study showed that during the period of $7 \mathrm{DAFI}$ to $17 \mathrm{DASI}$, the $\mathrm{Y}_{\mathrm{S}}$ was decreased more in the undrained treatment by (about 40-90 kPa) relative to the most drained treatment throughout the season, which coincided with increased $\mathrm{Na}^{+}$concentrations (25-70\%) and decreased $\mathrm{K}^{+}$concentrations (9-20\%) in leaves, resulting in a higher $\mathrm{Na}^{+} / \mathrm{K}^{+}$ratio. These changes were all strongly correlated with the reduced growth and yield of sunflower (Fig. 8). The second possible cause of the beneficial effect of drainage derives from the analysis of Barrett-Lennard and Shabala (2013). There is now a substantial body of published evidence that suggests that when root-zones become waterlogged (i.e., hypoxic), plants lose their ability to maintain their regulation of $\mathrm{Na}^{+}$exclusion and $\mathrm{K}^{+}$uptake, which can also increase the concentrations of $\mathrm{Na}^{+}$and decrease $\mathrm{K}^{+}$in the leaf tissues, leading to reduced plant growth and yield (Barrett-Lennard and Shabala 2013).

For both of these scenarios, $\mathrm{Na}^{+}$is taken up from the soil by roots and transported to the leaf through the xylem in response to transpiration (Yu and Assmann 2016). Excessive $\mathrm{Na}^{+}$accumulation in the cytosol due to hypoxia and salinity, enhances leakage of $\mathrm{K}^{+}$from root cells, $\mathrm{Na}^{+}$blocking of the $\mathrm{K}^{+}-$ specific transporters in the root cells and the increased $\mathrm{Na}^{+} / \mathrm{K}^{+}$ratio in leaves (Zhu 2003) can result in osmotic damage and disorder enzyme activation and protein synthesis (Tester and Davenport 2003), which might be plausible reasons for reduced crop growth and yield. 
In our study, $\mathrm{Na}^{+}$and $\mathrm{Na}^{+} / \mathrm{K}^{+}$ratios in sunflower leaves in the undrained treatment (soil EC $\mathrm{H}_{1: 5}$ at $0-15 \mathrm{~cm}$ depth: $0.25-0.58 \mathrm{dS} \mathrm{m}{ }^{-1} ; \mathrm{SEW}_{30}: 235-240 \mathrm{~cm}$ days) early in the season (7 DAFI-10 DASI) were 25-70 and 47-108\% higher, respectively, relative to the most drained treatment (soil $\mathrm{EC}_{1: 5}$ at $0-15 \mathrm{~cm}$ : 0.11-0.38 dS m ${ }^{-1} ; S_{30}: 89-95 \mathrm{~cm}$ days). We are aware of one other study which has reported the effects of hypoxia and salinity on the concentration of $\mathrm{Na}^{+}$in 50-day old sunflower (cv. Grey stripe) grown in nutrient solution (Kriedemann and Sands 1984). In this work, the combination of salinity (50 mM $\mathrm{NaCl}$ ) and hypoxia (bubbling with $\mathrm{N}_{2}$ gas) from days 24 to 50 increased $\mathrm{Na}^{+}$concentration in leaves 35 -fold relative to aerated non-saline conditions; by contrast, salinity alone increased $\mathrm{Na}^{+}$concentration by 4.5-fold. In addition, hypoxia from the plant age of 20 days to 30 days along with 4 days (21-24 days of the plant) salinization $(150 \mathrm{mM} \mathrm{NaCl})$ increased the $\mathrm{Na}^{+} / \mathrm{K}^{+}$ratio in leaves 6.8 -fold relative to aerated non-saline conditions.

In our study, we also found that $\mathrm{Na}^{+}$and $\mathrm{Na}^{+} / \mathrm{K}^{+}$ratios in older leaves at $10 \mathrm{DASI}$ under waterlogged saline conditions were around 350-400 and 450$500 \%$ higher than in younger leaves, respectively. This is supported by an earlier study (de Azevedo Neto et al. 2020) which reported that $\mathrm{Na}^{+}$and $\mathrm{Na}^{+} / \mathrm{K}^{+}$ ratios were about 70 and $585 \%$ higher, respectively, in older leaves of sunflower (cv. AG967) relative to younger leaves during the vegetative stage (at 35 days after germination) under saline conditions ( $100 \mathrm{mM} \mathrm{NaCl}$ for 20 days). Salts are continuously deposited in leaves through the transpiration stream, and salt accumulation in leaves therefore gradually increases with time. Relative to the import in the transpiration stream, there is little re-translocation of salt from older leaves. The presence of salt in leaves, already absorbed, therefore continues despite the salt around the root being removed (Munns 2002), so salt concentrations remain higher in older than in younger leaves. As $\mathrm{Na}^{+}$may block the $\mathrm{K}^{+}$-specific transporters, the leaf $\mathrm{Na}^{+}$and $\mathrm{Na}^{+} / \mathrm{K}^{+}$ratios increase and $\mathrm{K}^{+}$concentration decreases under saline conditions. Overall, all the studies reported significant differences in $\mathrm{Na}^{+}$and $\mathrm{K}^{+}$in sunflower leaves between waterlogged and/or saline treatment and drained and/or least-saline treatment. The results are consistent with the view that the implementation of drainage systems can mitigate soil salinity and waterlogging, decreasing the leaf $\mathrm{Na}^{+}$and $\mathrm{Na}^{+} / \mathrm{K}^{+}$ratio and improving plant growth and yield (Hou et al. 2016; Islam et al. 2021; Ritzema et al. 2008).

\section{Stomatal closure}

The $g_{\mathrm{s}}$ of leaves control $\mathrm{CO}_{2}$ uptake and transpiration, which affect photosynthesis, and water and nutrient uptake (Farooq et al. 2009). Increased salt concentration (i.e., decreased $\mathrm{Y}_{\mathrm{s}}$ of the soil) and waterlogging stresses enhance the efflux of $\mathrm{K}^{+}$from stomatal guard cells, leading to the loss of cell turgor, which induces stomatal closure that reduces $\mathrm{CO}_{2}$ assimilation and photosynthetic rate, resulting in reduced carbohydrate production and less water and nutrient uptake (Lambers and Bassham 2021). These conditions can also lead to the accumulation of toxic metabolites, combined with an increase in free radicles/reactive oxygen species (ROS), decreased evaporative cooling, a decrease in LCC, leading to cell death (Zhang et al. 2017; Zheng et al. 2009), all of which might be causes of reduced plant growth and yield.

In the present study, we found decreases in $g_{\mathrm{s}}$ associated with the undrained treatment early in the season. These lower $g_{\mathrm{s}}$ linked to increased SEW 30 and soil $\mathrm{EC}_{1: 5}$, and decreased $\mathrm{Y}_{\mathrm{S}}$ (Supplementary Material, Table S3) were correlated with reduced achene yield. In our work, the undrained treatment had a decreased $g_{\mathrm{s}}(37 \%)$ at $3 \mathrm{DASI}$, although there was no difference in $g_{\mathrm{s}}$ between drained and undrained treatments at the later times of measurement (Table 2), suggesting that the plants recovered after waterlogging. The $Y_{\text {leaf }}$ of sunflower was $0.11-0.25 \mathrm{MPa}$ higher (less negative) in the undrained treatment relative to the most drained treatment (Table 3). Waterlogging is known to decrease the stomatal conductance in a range of dicots including: sunflower (Kriedemann and Sands 1984), tomato (Jackson et al. 1978; Bradford and Hsiao 1982) and a range of tree species (Pereira and Kozlowski 1977; Sena Gomes and Kozlowski 1980). Evidence from some of these studies (Jackson et al. 1978; Bradford and Hsiao 1982; Pereira and Kozlowski 1977) shows that these decreases in conductance were not associated with decreases in $Y_{\text {leaf }}$, suggesting that the plants communicate the presence of waterlogging to the leaves by means of a chemical/hormonal signal, believed to be abscisic acid (Pan et al. 2020). Our observation of a recovery in $g_{\mathrm{s}}$ by 10 days after waterlogging in sunflower in the field, is consistent with the results from a previous study with Fraxinus pennsy/vanica that stomata closed due to waterlogging began to reopen after 15 days; in this study, the recovery in $g_{\mathrm{s}}$ was associated with the formation of new adventitious roots (Sena Gomes and Kozlowski 1980).

\section{The most drained treatment reduces soil solute potential late in the season, leading to decreases in plant growth and yield}

Generally, at the end (March-April) of the dry rabi season, soil salinity increases and SWC decreases in the study area (Rahman et al. 2015; Salehin et al. 2018). Based on previous studies, we hypothesized (incorrectly) that the presence of deep drains (i.e., excess drainage) might dry the soil early in the growing season, decreasing the availability of water late in the growing season and having an adverse effect on crop growth. The hypothesis may have been wrong because of light rainfall late in the growing season (flowering to harvest) and the presence of deep soil cracks in contact with the slotted pipe drains that actually delivered water to the subsoil. Another possibility is that the most drained plots had greater leaf area index (LAl), which could have protected the soil surface from direct sunlight and decreased soil evaporation, which could have maintained better crop growth and yield.

At the end of the season, the drained treatments had increased growth and yield, and yet the $Y_{\text {leaf }}$ were more negative with drainage, suggesting that the adverse effect on growth were not caused by adverse water relations. However, late in the season (flowering), we also found that the most drained treatment had lower leaf $\mathrm{Na}^{+}$and $\mathrm{Na}^{+} / \mathrm{K}^{+}$ratios than the undrained treatment. This indicates that shallow combined drains decreased leaf $\mathrm{Na}^{+}$and $\mathrm{Na}^{+} / \mathrm{K}^{+}$ ratios late in the dry season. This was due to higher soil water content and lower $\mathrm{EC}_{1: 5}$ (i.e., higher $\mathrm{Y}_{\mathrm{s}}$ ) in the combined drain treatment relative to the undrained treatment (Islam et al. 2021). It was also observed that in the younger leaves, $\mathrm{Na}^{+}$concentration and $\mathrm{Na}^{+} / \mathrm{K}^{+}$ratios decreased at the flowering stage relative to the earlier (10 DASI) stage (vegetative) of the sunflower. Measurements of $\mathrm{SEW}_{30}$ showed that there was no waterlogging at the end of the 
growing season (Islam et al. 2021). The increase in $\mathrm{Na}^{+}$concentration and $\mathrm{Na}^{+} / \mathrm{K}^{+}$ratios in leaves of undrained sunflower late in the season could not, therefore, have been caused by the waterlogging-salinity interactions discussed in the previous section.

How could the drains actually increase SWC? Our observations suggest that the drains appear to be 'watering' the plants. The soils of the Ganges Delta are generally 'shrink-swell' clays (Moslehuddin et al. 1999) that form deep cracks as the soil dries out (c.f. Paul et al. 2021b). It is likely that when rain falls on the soil surface late in the growing season, a large proportion of this water rapidly runs down these cracks. Interception of the cracks by the slotted pipe drains provides a route for this water to then be rapidly redistributed laterally through a whole plot, where it can then recharge the soil profile to depths greater than $50 \mathrm{~cm}$. At these depths in the bulk of the soil, there is less evaporation, so the water is conserved for later crop growth. By contrast, in undrained soils, there may still be some movement of rainwater to the bottom of cracks, but the water remains in the immediate locality of that crack where it is susceptible to more rapid evaporation, which is exacerbated by the lower soil shading due to lower LAI (Islam et al. 2021; Villalobos and Fereres 1990). We conclude that drained soils experience better rather than worse water relations at the end of the growing season.

It should be noted that our explanation for these effects requires the combination of cracks plus drains to harvest late season rainfall. In situations where there was no late season rainfall, the combination of cracks plus drains may be even worse for crop yields than in the undrained soils. The key question is whether plants late in the season used predominantly rainwater associated with subsurface drains or groundwater or both. The sources of water being used by plants could be investigated by measuring the stable isotope composition of water $\left(\delta \mathrm{D}\right.$ and $\left.\delta^{18} \mathrm{O}\right)$ if the isotopic signatures vary between the groundwater and rainwater. For example, based on different isotopic signatures in groundwater and rainwater, Mensforth et al. (1994) and Thorburn and Walker (1993) concluded that groundwater was the dominant source of water for trees, despite its salinity, but the proportion of groundwater used by trees declined after rainfall.

\section{Conclusion}

In a salt-affected, waterlogged coastal zone clay soil in the Ganges Delta, shallow drains improved sunflower growth and yield by increasing the $Y_{S}$ of soil, leaf $\mathrm{K}^{+}$and $g_{\mathrm{s}}$, and decreasing leaf $\mathrm{Na}^{+}$and $\mathrm{Na}^{+} / \mathrm{K}^{+}$ratio. However, the $\mathrm{Y}_{\text {leaf }}$ increased in the undrained treatment. Indeed, decreased $\mathrm{Y}_{\text {leaf }}$ was significantly correlated with increased LA and plant height. Early in the season, the most drained treatment (SSD+SD) reduced the waterlogging and soil salinity impacts on the plant-water relations and ion concentrations in leaves of sunflower more efficiently than other treatments. In the late-season, shallow combined drains increased $Y_{S}$ of soil by increasing water availability and reducing soil salinity, resulting in better plant-water and ion relations.

\section{Declarations}

\section{Acknowledgments}

We would like to gratefully acknowledge all the staff at the Soil Science Division and Irrigation and Water Management Division, Bangladesh Rice Research Institute and Agro-technology Discipline, Khulna University, Bangladesh, for their kind assistance to analyze soil and plant samples. Special thanks to landowner Asim Bala, who provided the land for conducting research. We also wish to express our heartiest thanks to the Australian Centre for International Agricultural Research (Project LWR/2014/073) for grants and awarding John Allwright Fellowship (JAF).

Funding: Australia Centre for International Agricultural Research (ACIAR) provided the funds for the research (LWR/2015/073) and a John Allwright Fellowship to the senior author.

Conflicts of Interest: The authors declare that they have no conflict of interest.

Availability of data and material: The datasets generated and analyzed during the current study are available from the corresponding author on reasonable request.

Code availability: Not applicable

Authors' contributions: All authors contributed to the study conceptualization, design and methodology. Data collection was performed by Mohammad Nazrul Islam, and data analyses were performed by Mohammad Nazrul Islam, Richard W. Bell and Edward G. Barrett-Lennard. The first draft of the manuscript was written by Mohammad Nazrul Islam, and all authors were involved in the revision and editing of the draft manuscript and have approved the final content.

Ethics approval: Not applicable

Consent to participate: Not applicable

Consent for publication: Not applicable

This manuscript is a portion of a PhD thesis (Islam, MN), which will be submitted to Murdoch University, WA-6150, Australia.

\section{References}


1. Akram MS, Ashraf M, Akram NA (2008) Effectiveness of potassium sulfate in mitigating salt-induced adverse effects on different physio-biochemical attributes in sunflower (Helianthus annuus L.). Flora 204:471-483. https://doi.org/10.1016/j.flora.2008.05.008

2. Barrett-Lennard EG (2003) The interaction between waterlogging and salinity in higher plants: causes, consequences and implications. Plant Soil 253:35-54. https://doi.org/10.1023/A:1024574622669

3. Barrett-Lennard EG, Shabala SN (2013) The waterlogging/salinity interaction in higher plants revisited-focusing on the hypoxia-induced disturbance to $\mathrm{K}^{+}$homeostasis. Funct Plant Biol 40:872-882. https://doi.org/10.1071/FP12235

4. Ben-Gal A, Borochov-Neori H, Yermiyahu U, Shani U (2009) Is osmotic potential a more appropriate property than electrical conductivity for evaluating whole-plant response to salinity? Environ Exp Bot 65:232-237. https://doi.org/10.1016/j.envexpbot.2008.09.006

5. Bradford KJ, Hsiao TC (1982) Stomatal behavior and water relations of waterlogged tomato plants. Plant Physiol 70:1508-1513. https://doi.org/10.1104/pp.70.5.1508

6. Cox JW (1988) Seepage interceptor drainage of duplex soils in south-western Australia. Doctoral dissertation, The University of Western Australia, Australia

7. Dagar JC, Minhas P (2016) Agroforestry for the management of waterlogged saline soils and poor-quality waters. In: Dagar JC, Minhas PS (eds) Advances in Agroforestry, vol 13. Springer, India

8. Darzi-Naftchali A, Mirlatifi SM, Shahnazari A, Ejlali F, Mahdian MH (2013) Effect of subsurface drainage on water balance and water table in poorly drained paddy fields. Agric Water Manag 13:61-68. https://doi.org/10.1016/j.agwat.2013.08.017

9. de Azevedo Neto AD, Mota KNAB, Silva PCC, Cova AMW, Ribas RF, Gheyi HR (2020) Selection of sunflower genotypes for salt stress and mechanisms of salt tolerance in contrasting genotypes. Ciência e Agrotecnologia 44:e020120. https://doi.org/10.1590/1413-7054202044020120

10. Elsheikh ERA, Schultz B, Haili AM, Adam HS (2012) Effect of deficit irrigation on yield and yield components of sunflower on Gezira clay soil, Sudan. WIT Trans Ecol Environ 168:369-378. https://doi.org/10.2495/SI120321

11. Falakboland Z, Zhou M, Zeng F, Kiani-Pouya A, Shabala L, Shabala S (2017) Plant ionic relation and whole-plant physiological responses to waterlogging, salinity and their combination in barley. Funct Plant Biol 44:941-953. https://doi.org/10.1071/FP16385

12. Farooq M, Wahid A, Kobayashi N, Fujita D, Basra SMA (2009) Plant drought stress: effects, mechanisms and management. Agron Sustain Dev 29:185-212. https://doi.org/10.1051/agro:2008021

13. Gupta SK (2002) A century of subsurface drainage research in India. Irrig Drain Syst 16:69-84. https://doi.org/10.1023/A:1015525405522

14. Hou M, Zhu L, Jin Q (2016) Surface drainage and mulching drip-irrigated tomatoes reduces soil salinity and improves fruit yield. PLoS ONE 11:e0154799. https://doi.org/10.1371/journal.pone.0154799

15. Hu Y, Schmidhalter U (2004) Limitation of salt stress to plant growth. In: Elstner HA (ed) Plant Toxicology, 4th edn. Marcel Dekker Inc, New York, pp 191-224

16. Hunt R (1982) Plant growth curves: the functional approach to plant growth analysis. Edward Arnold Ltd, London

17. Islam MN, Bell RW, Barrett-Lennard EG, Maniruzzaman M (2021) Shallow surface and subsurface drains alleviate waterlogging and salinity in a claytextured soil and improve the yield of sunflower in the Ganges Delta. Agron Sustain Dev (accepted on 1 December 2021)

18. Jackson MB, Gales K, Campbell DJ (1978) Effect of waterlogged soil conditions on the production of ethylene and on water relationships in tomato plants. J Exp Bot 29:183-193. https://doi.org/10.1093/jxb/29.1.183

19. Katerji N, van Hoorn JW, Hamdy A, Karam F, Mastrorilli M (1996) Effect of salinity on water stress, growth, and yield of maize and sunflower. Agric Water Manag 30:237-249. https://doi.org/10.1016/0378-3774(95)01228-1

20. Kirmizi S, Bell RW (2012) Responses of barley to hypoxia and salinity during seed germination, nutrient uptake, and early plant growth in solution culture. J Plant Nutr Soil Sci 175:630-640. https://doi.org/10.1002/jpln.201100209

21. Kriedemann PE, Sands R (1984) Salt resistance and adaptation to root-zone hypoxia in sunflower. Funct Plant Biol 11:287-301. https://doi.org/10.1071/PP9840287

22. Lambers H, Bassham JA (2021) Photosynthesis. Encyclopedia Britannica. https://www.britannica.com/science/photosynthesis. Accessed 23 November 2021

23. Mainuddin M, Karim F, Gaydon DS, Kirby JM (2021) Impact of climate change and management strategies on water and salt balance of the polders and islands in the Ganges delta. Sci Rep 11:1-15. https://doi.org/10.1038/s41598-021-86206-1

24. Mensforth LJ, Thorburn PJ, Tyerman SD, Walker GR (1994) Sources of water used by riparian Eucalyptus camaldulensis overlying highly saline groundwater. Oecologia 100:21-28. https://doi.org/10.1007/BF00317126

25. Moslehuddin AZ, Hussain MS, Saheed SM, Egashira K (1999) Clay mineral distribution in correspondence with agroecological regions of Bangladesh soils. Clay Sci 11:83-94. https://doi.org/10.11362/jcssjclayscience1960.11.83

26. Munns R (2002) Comparative physiology of salt and water stress. Plant Cell Environ 25:239-250. https://doi.org/10.1046/j.0016-8025.2001.00808.x

27. Pan J, Sharif R, Xu X, Chen X (2020) Mechanisms of waterlogging tolerance in plants: Research progress and prospects. Front Plant Sci $11: 627331$. https://doi.org/10.3389/fpls.2020.627331

28. Paul PLC, Bell RW, Barrett-Lennard EG, Kabir E (2020) Variation in the yield of sunflower (Helianthus annuus L.) due to differing tillage systems is associated with variation in solute potential of the soil solution in a salt-affected coastal region of the Ganges Delta. Soil Tillage Res 197:104489. https://doi.org/10.1016/j.still.2019.104489

Page $11 / 18$ 
29. Paul PLC, Bell RW, Barrett-Lennard EG, Kabir E, Gaydon DS (2021a) Opportunities and risks with early sowing of sunflower in a salt-affected coastal region of the Ganges Delta. Agron Sustain Dev 41:39. https://doi.org/10.1007/s13593-021-00698-9

30. Paul PLC, Bell RW, Barrett-Lennard EG, Kabir E (2021b) Impact of rice straw mulch on soil physical properties, sunflower root distribution and yield in a salt-affected clay-textured soil. Agriculture 11:264. https://doi.org/10.3390/agriculture11030264

31. Paul PLC, Bell RW, Barrett-Lennard EG, Kabir E, Mainuddin M, Sarker KK (2021c) Short-term waterlogging depresses early growth of sunflower (Helianthus annuus L.) on saline soils with a shallow water table in the coastal zone of Bangladesh. Soil Syst 5(4):68. https://doi.org/10.3390/soilsystems5040068

32. Pereira JS, Kozlowski TT (1977) Variations among woody angiosperms in response to flooding. Physiol Plant 41:184-192. https://doi.org/10.1111/j.1399-3054.1977.tb05555.x

33. Rahman MN, Amin MGM, Mondal MK, Humphreys E (2015) Rabi crop establishment methods for increasing land productivity in the coastal zone of Bangladesh. In: Conference on Revitalizing the Ganges Coastal Zone: Turning Science into Policy and Practices, Dhaka, Bangladesh, 21-23 October 2015. CGIAR Challenge Program on Water and Food (CPWF), pp 504-515

34. Rengasamy P (2006) World salinization with emphasis on Australia. J Exp Bot 57:1017-1023. https://doi.org/10.1093/jxb/erj108

35. Ritzema HP, Satyanarayana TV, Raman S, Boonstra J (2008) Subsurface drainage to combat waterlogging and salinity in irrigated lands in India: Lessons learned in farmers' fields. Agric Water Manag 95:179-189. https://doi.org/10.1016/j.agwat.2007.09.012

36. Salehin M, Chowdhury MMA, Clarke D, Mondal S, Nowreen S, Jahiruddin M, Haque A (2018) Mechanisms and drivers of soil salinity in coastal Bangladesh. In: Nicholls RJ et al (eds) Ecosystem services for well-being in deltas. Springer Nature, Cham, Switzerland, pp 333-347

37. Saqib M, Akhtar J, Qureshi RH (2005) $\mathrm{Na}^{+}$exclusion and salt resistance of wheat (Triticum aestivum) in saline-waterlogged conditions are improved by the development of adventitious nodal roots and cortical root aerenchyma. Plant Sci 169:125-130. https://doi.org/10.1016/j.plantsci.2005.03.003

38. Schneiter AA, Miller JF (1981) Description of sunflower growth stages. Crop Sci 21:901-903. https://doi.org/10.2135/cropsci1981.0011183X002100060024x

39. Sena Gomes ARS, Kozlowski TT (1980) Growth responses and adaptations of Fraxinus pennsy/vanica seedlings to flooding. Plant Physiol 66:267271. https://doi.org/10.1104/pp.66.2.267

40. Sharma DP, Singh K, Rao KVGK (2000) Subsurface drainage for rehabilitation of waterlogged saline lands: example of a soil in semiarid climate. Arid Soil Res Rehabil 14:373-386. https://doi.org/10.1080/08903060050136478

41. Shaw RE (2015) Plant waterlogging: causes, responses, adaptations and crop models. Doctoral dissertation, University of Adelaide, Australia

42. Sieben WH (1964) Relationship between drainage conditions and crop yield for young light clay soils in the Nordost polder. Van Zee tot Lod. 40. Tjeenk Willink V, Zwolle, The Netherlands

43. SRDI (2010) Saline soils of Bangladesh. Retrieved from Dhaka, Bangladesh:

http://srdi.portal.gov.bd/sites/default/files/files/srdi.portal.gov.bd/publications/bc598e7a_df21_49ee_882e_0302c974015f/Soil\%20salinity\%20reportNov\%202010.pdf. Accessed on 22 November 2020

44. Tester M, Davenport R (2003) $\mathrm{Na}^{+}$tolerance and $\mathrm{Na}^{+}$transport in higher plants. Ann Bot 91:503-527. https://doi.org/10.1093/aob/mcg058

45. Thorburn PJ, Walker GR (1993) The source of water transpired by Eucalyptus camaldulensis: soil, groundwater or streams. In: Ehleringer JR, Hall AE, Farquhar GD (eds) Stable isotopes in plant carbon-water relations. Academic Press, San Diego, pp 511-527. https://doi.org/10.1016/B978-0-08091801-3.50042-8

46. van der Zee Sjored EATM, Stofberg SF, Yang X, Liu Y, Islam MN, Hu YF (2017) Irrigation and drainage in agriculture: a salinity and environmental perspective. In: Kulshreshtha S, Elshorbagy A (eds) Current Perspective on Irrigation and Drainage. IntechOpen, London, UK, pp 1-21

47. Villalobos FJ, Fereres E (1990) Evaporation measurements beneath corn, cotton, and sunflower canopies. Agron J 82(6):1153-1159. https://doi.org/10.2134/agronj1990.00021962008200060026x

48. Wu GQ, Jiao Q, Shui QZ (2015) Effect of salinity on seed germination, seedling growth, and inorganic and organic solutes accumulation in sunflower (Helianthus annuus L.). Plant Soil Environ 61:220-226. https://doi.org/10.17221/22/2015-PSE

49. Yamakawa T (1992) Laboratory methods for soil science and plant nutrients. IPSA-JICA publication No.2. IPSA, Gazipur, Bangladesh

50. Yu Y, Assmann SM (2016) The effect of $\mathrm{NaCl}$ on stomatal opening in Arabidopsis wild type and agb1 heterotrimeric G-protein mutant plants. Plant Signal Behav 11(2):e1085275. https://doi.org/10.1080/15592324.2015.1085275

51. Yu Y, Mainuddin M, Maniruzzaman M, Mandal UK, Sarangi SK (2019) Rainfall and temperature characteristics in the coastal zones of Bangladesh and West Bengal, India. J Indian Soc Coast Agric Res 37:12-23

52. Zhang P, Lyu D, Jia L, He J, Qin S (2017) Physiological and de novo transcriptome analysis of the fermentation mechanism of Cerasus sachalinensis roots in response to short-term waterlogging. BMC Genomics 18:649. https://doi.org/10.1186/s12864-017-4055-1

53. Zheng C, Jiang D, Liu F, Dai T, Jing Q, Cao W (2009) Effects of salt and waterlogging stresses and their combination on leaf photosynthesis, chloroplast ATP synthesis, and antioxidant capacity in wheat. Plant Sci 176(4):575-582. https://doi.org/10.1016/j.plantsci.2009.01.015

54. Zhu JK (2003) Regulation of ion homeostasis under salt stress. Curr Opin Plant Biol 6:441-445. https://doi.org/10.1016/S1369-5266(03)00085-2

\section{Figures}




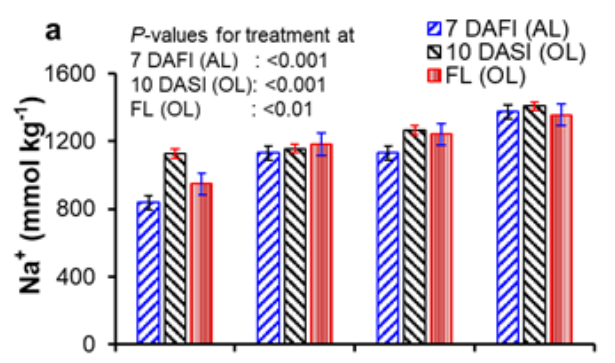

\section{d}

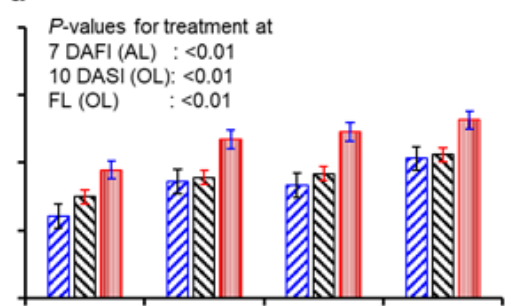

b

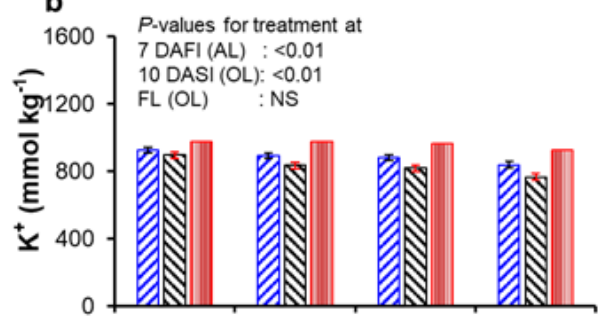

e

$P$-values for treatment at

7 DAFI (AL) : $<0.05$

$10 \mathrm{DASI}(\mathrm{OL}):<0.01$

FL (OL) : NS
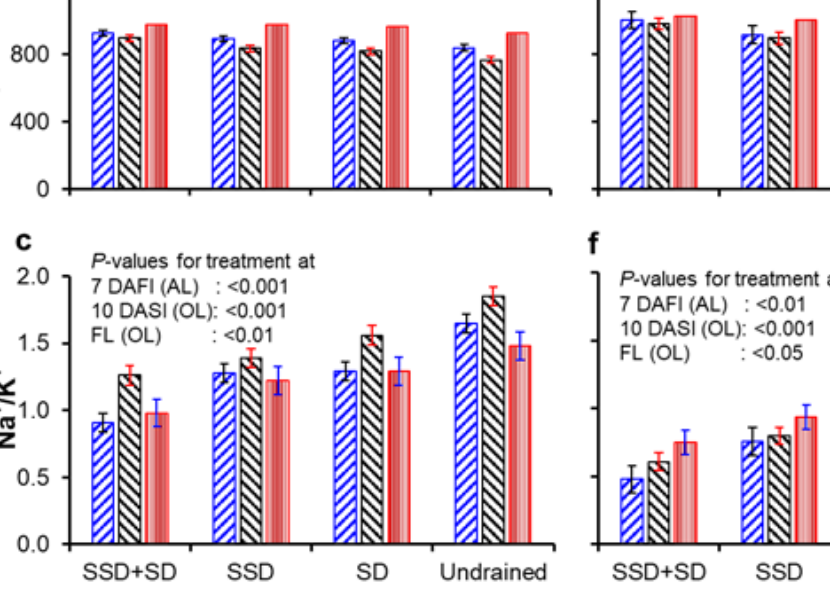

f

7.values for treatment at

7 DAFI (AL) : $<0.01$

$10 \mathrm{DASI}(\mathrm{OL}):<0.001$

$\mathrm{FL}(\mathrm{OL}) \quad:<0.05$

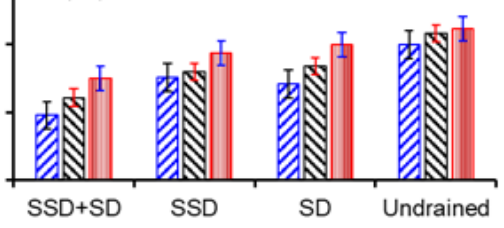

Treatment

\section{Figure 1}

Effect of drains on the concentration of $\mathrm{Na}$ and $\mathrm{K}$ ions in leaves and its ratio $\left(\mathrm{Na}^{+} / \mathrm{K}^{+}\right)$in $2018-19(\mathrm{a}-\mathrm{c})$ and $2019-20(\mathrm{~d}-\mathrm{f})$. Abbreviations: SSD = subsoil drain, $\mathrm{SD}=$ surface drain, $\mathrm{DAFI}=$ days after first inundation, $\mathrm{DASI}=$ days after second inundation, $\mathrm{FL}=$ flowering, $\mathrm{AL}=\mathrm{all}$ leaves, $\mathrm{OL}=\mathrm{older}$ leaves. $\mathrm{Vertical}$ bars at the top of columns indicate the LSD at $5 \%$ level of significance. 


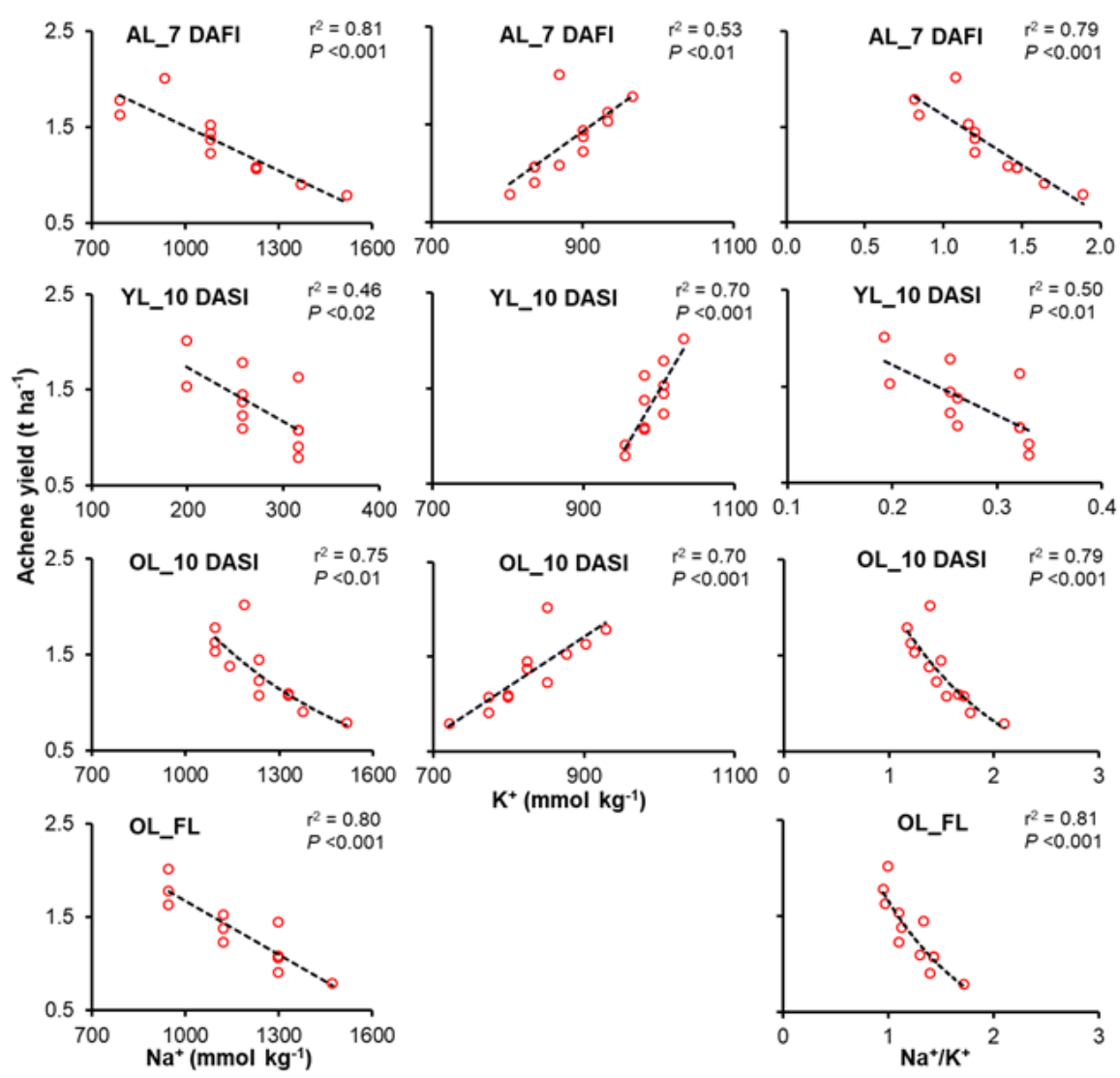

Figure 2

Correlation between achene yield and $\mathrm{Na}^{+}$or $\mathrm{K}^{+}$or $\mathrm{Na}^{+} / \mathrm{K}^{+}$in leaves at different times in $2018-19$. Abbreviations: DAFI = days after first inundation, $\mathrm{DASI}=$ days after second inundation, $\mathrm{FL}=$ flowering, $\mathrm{AL}=$ all leaves, $\mathrm{YL}=$ younger leaves, $\mathrm{OL}=$ older leaves.
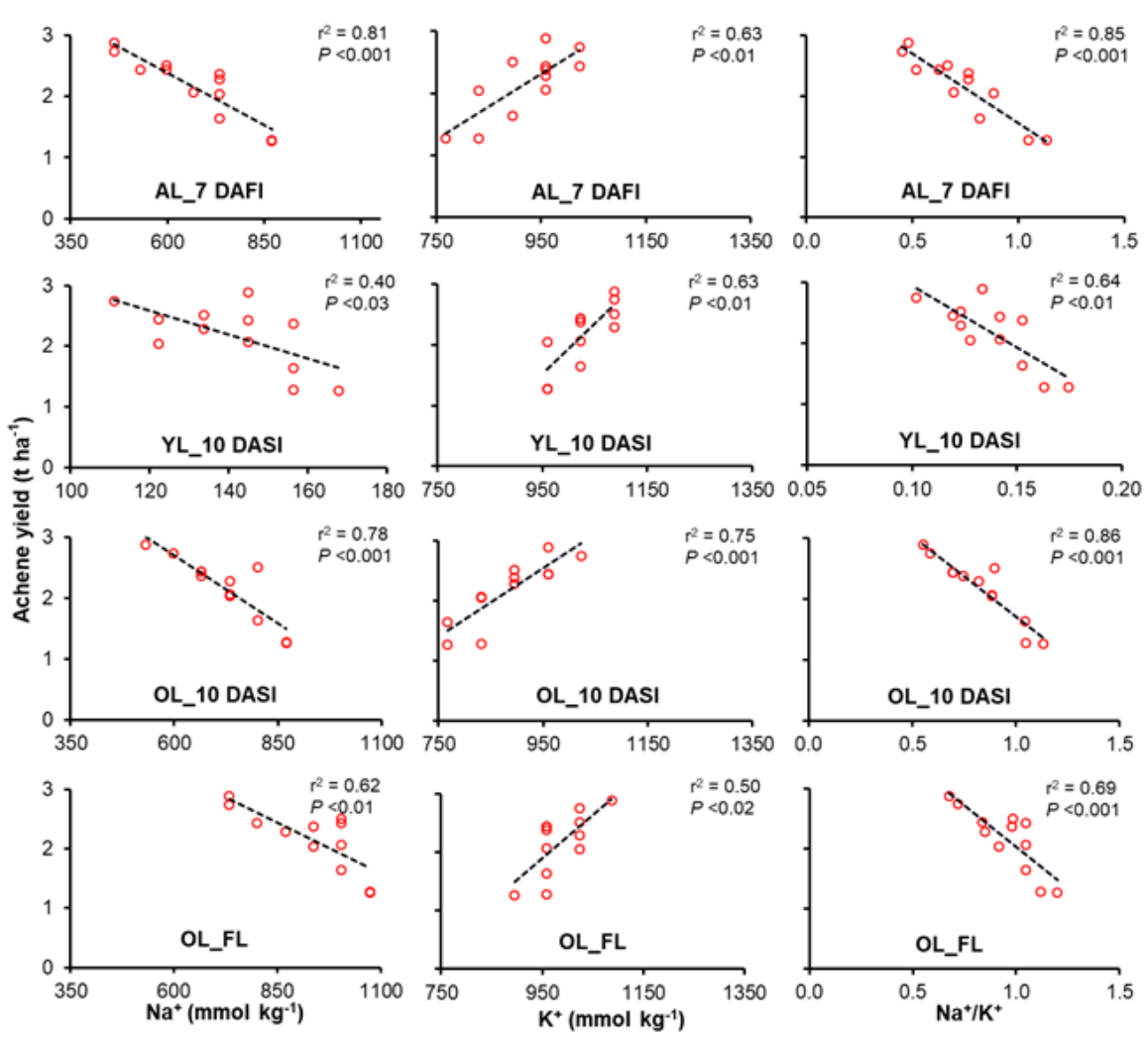
Figure 3

Correlation between achene yield and $\mathrm{Na}^{+}$or $\mathrm{K}^{+}$or $\mathrm{Na}^{+} / \mathrm{K}^{+}$in leaves at different times in 2019-20. Abbreviations: DAFI = days after first inundation, DASI = days after second inundation, $\mathrm{FL}=$ flowering, $\mathrm{AL}=$ all leaves, $\mathrm{YL}=$ younger leaves, $\mathrm{OL}=$ older leaves.

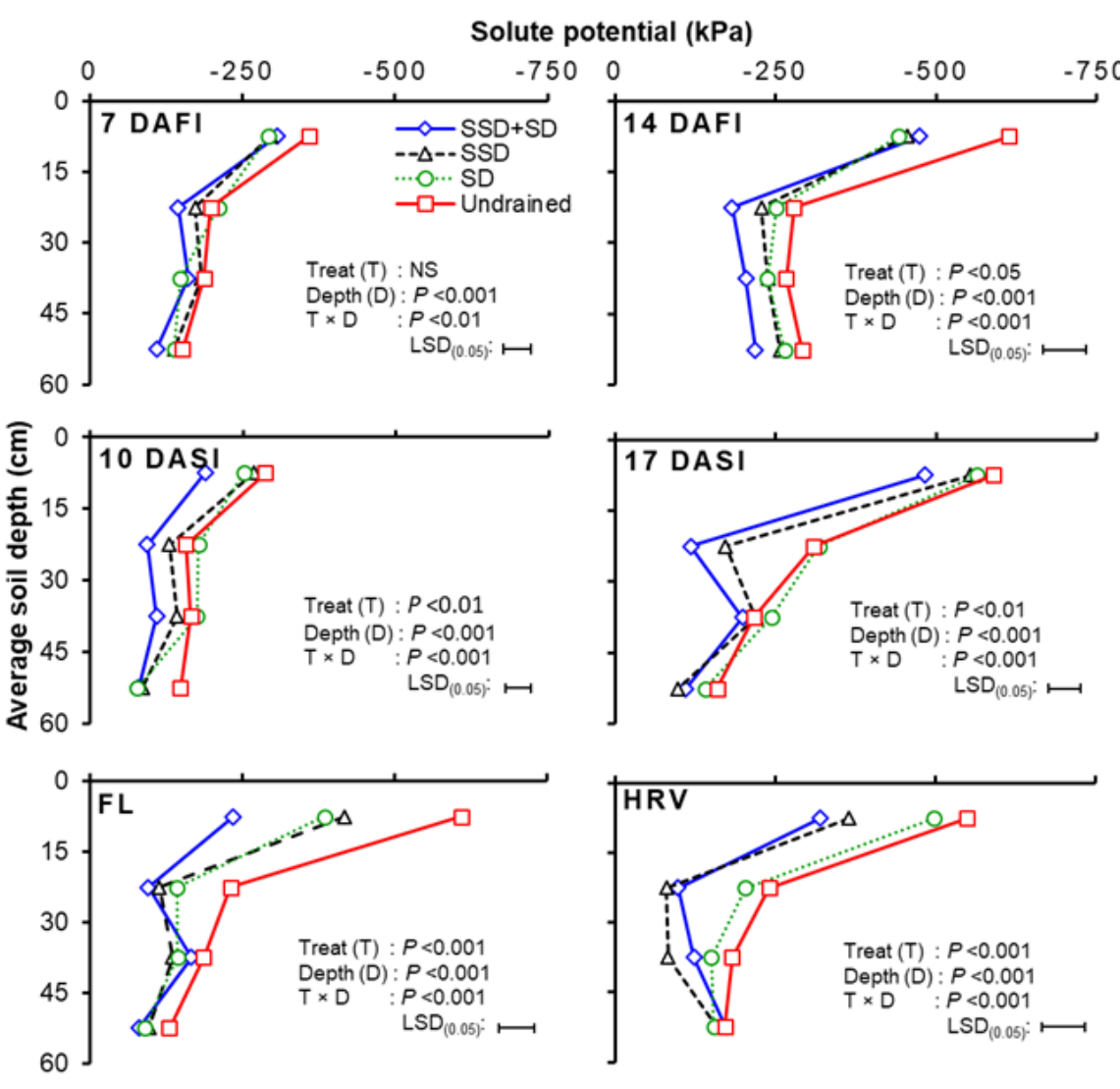

\section{Figure 4}

Effect of different drains on solute potential at different soil depths at different times during the crop growing season in Dacope, Bangladesh, in $2018-19$. Abbreviations: $\mathrm{SSD}=$ subsoil drain, $\mathrm{SD}=$ surface drain, $\mathrm{DAFI}=$ days after first inundation, $\mathrm{DASI}=$ days after second inundation, $\mathrm{FL}=\mathrm{flowering}, \mathrm{HRV}=$ harvest. 


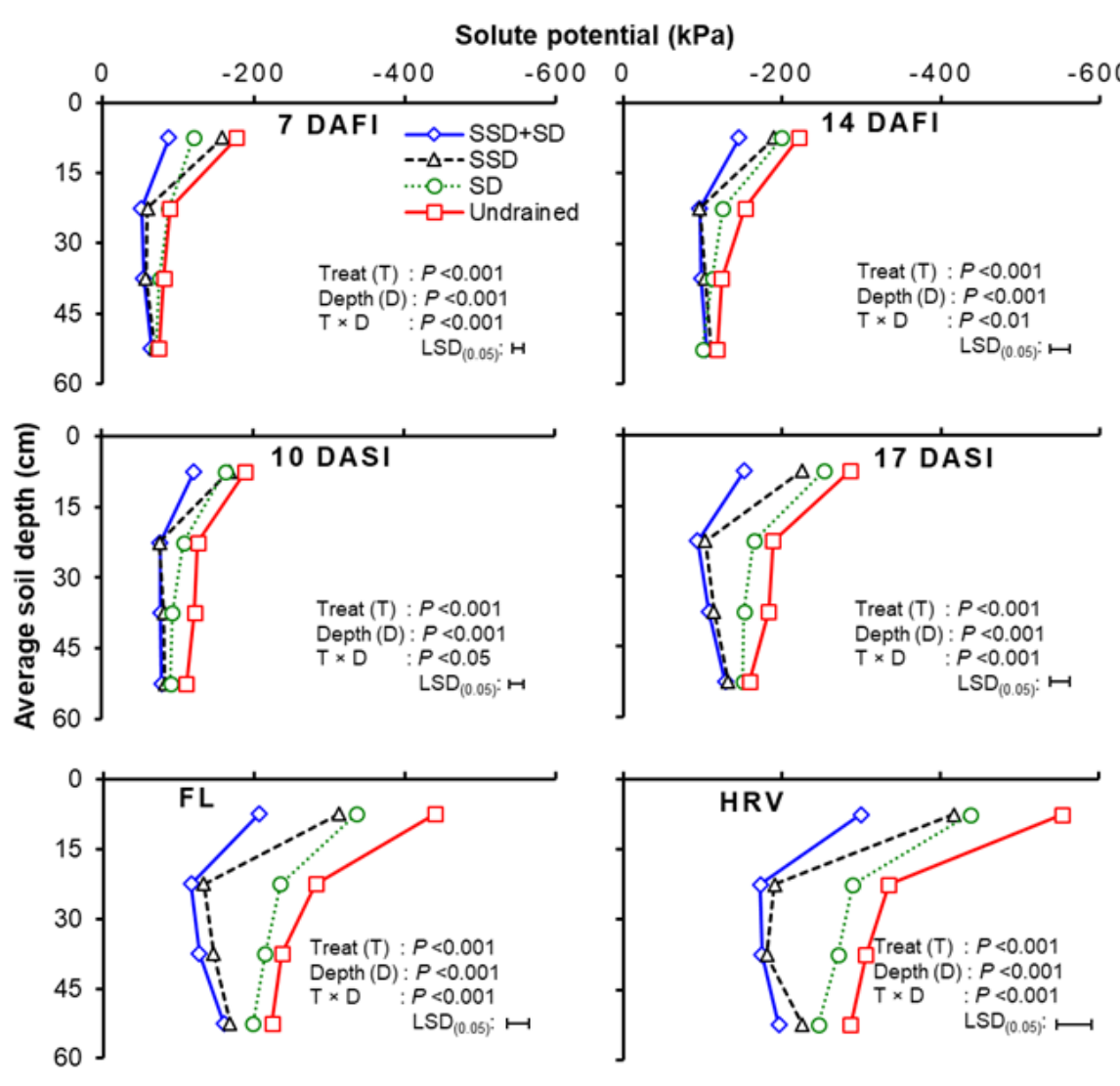

\section{Figure 5}

Effect of different drains on solute potential at different soil depths at different times during the crop growing season in Dacope, Bangladesh, in 2019-20. Abbreviations: $\mathrm{SSD}=$ subsoil drain, $\mathrm{SD}=$ surface drain, $\mathrm{DAFI}=$ days after first inundation, $\mathrm{DASI}=$ days after second inundation, $\mathrm{FL}=\mathrm{flowering}, \mathrm{HRV}=$ harvest. 


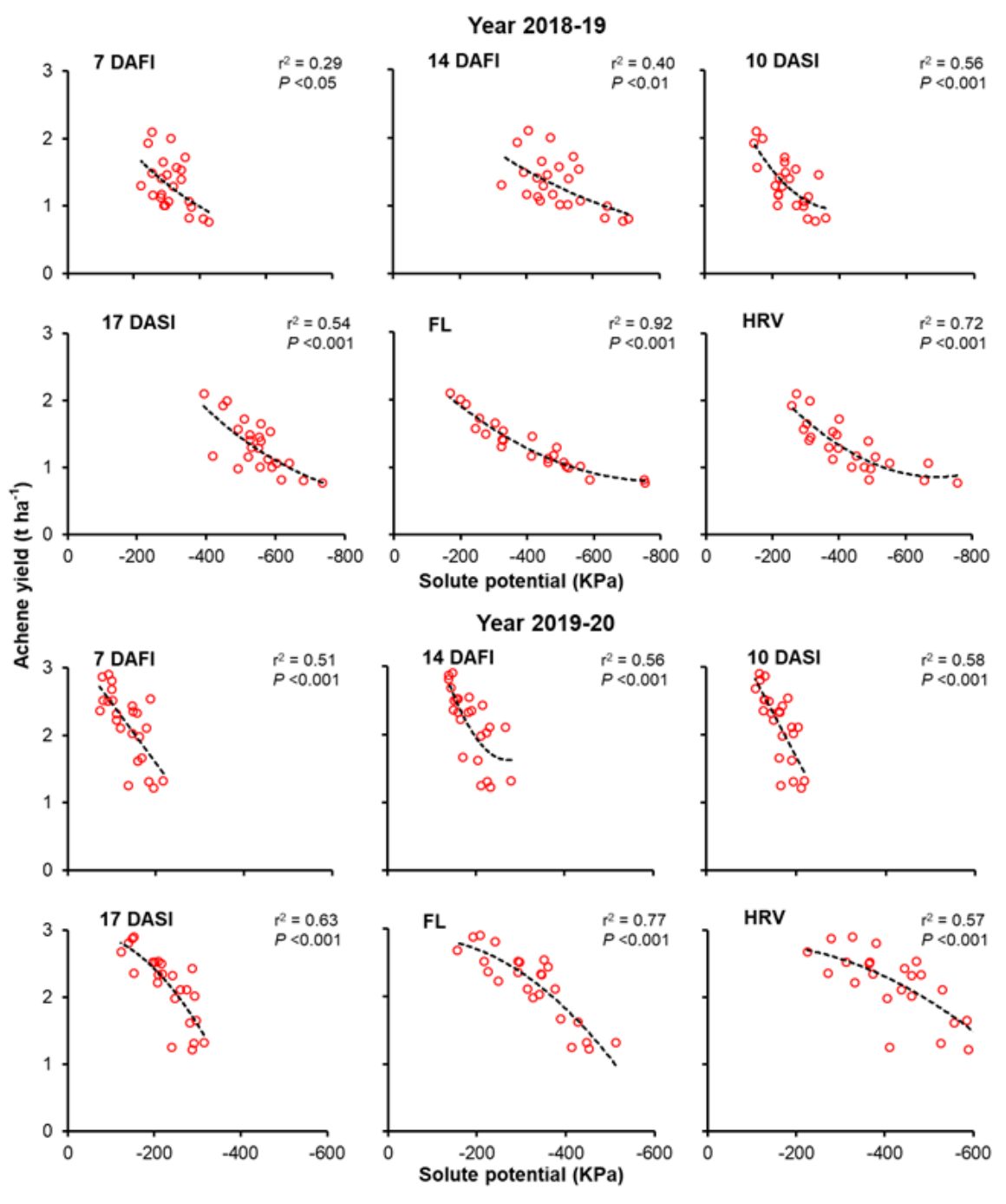

Figure 6

Relationship between sunflower yield and solute potential at $0-15 \mathrm{~cm}$ soil depth at different times during the crop growing period in Dacope, Bangladesh, in 2018-19 and 2019-20. Abbreviations: DAFI = days after first inundation, DASI = days after second inundation, FL = flowering, HRV = harvest.

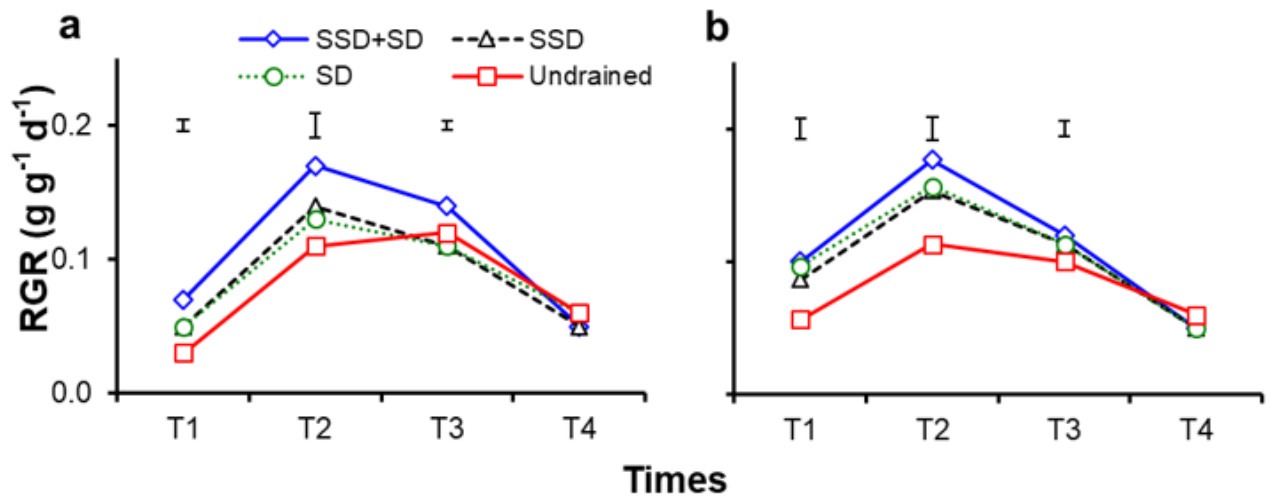

\section{Figure 7}

Effect of drains on the RGR of the shoot during the cropping season in 2018-19 (a) and 2019-20 (b). Abbreviations: RGR = relative growth rate, T1 = before inundation to 7 days after first inundation (DAFI), T2 = 7 DAFI to 14 DAFI, T3 = 10 days after second inundation (DASI) to 17 DASI and T4 = $17 \mathrm{DASI}$ to flowering. 


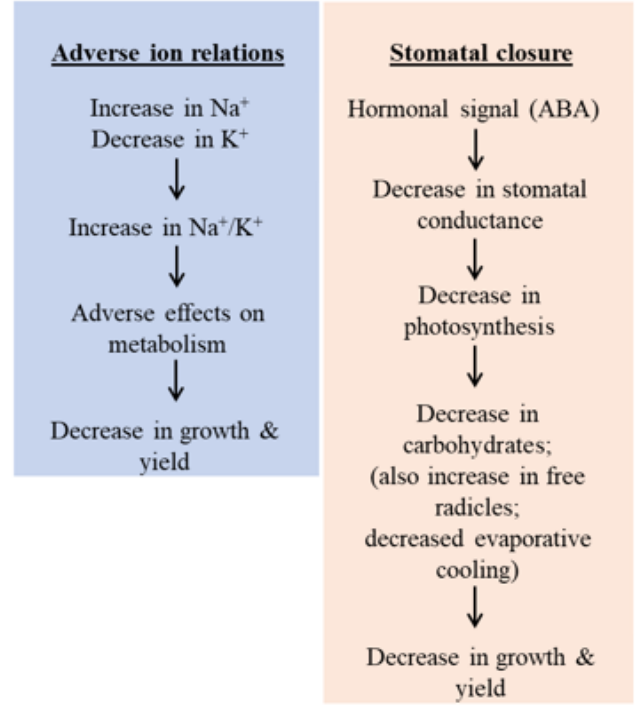

\section{Figure 8}

Schema of possible mechanisms of growth and yield reduction under waterlogged saline conditions early in the season. Abbreviations: $A B A=$ abscisic acid

\section{Supplementary Files}

This is a list of supplementary files associated with this preprint. Click to download.

- Supplementarymateriallslametal.docx 